\title{
63. UPPER MAESTRICHTIAN TO MIDDLE EOCENE STRATIGRAPHY OF THE NEW JERSEY SLOPE AND COASTAL PLAIN ${ }^{1}$
}

\author{
Richard K. Olsson, Department of Geological Sciences, Rutgers University \\ and \\ Sherwood W. Wise, Jr., Department of Geology, Florida State University ${ }^{2}$
}

\begin{abstract}
Five depositional sequences in the coastal plain of New Jersey are correlated with the middle Maestrichtian to middle Eocene record at DSDP Site 605. Four of these sequences correlate closely with sea-level sequences TP1, TP2, TE1, and TE2 of Vail and others (1977). A middle to upper Maestrichtian sequence is also correlated with Site 605. A type 1 unconformity separates sequences TP1 and TP2.1. At Site 605 this unconformity is associated with seismic reflector $A^{*}($ ?). In the coastal plain type 2 unconformities are associated with sequences KM1 (middle to upper Maestrichtian), TP2.1, 2.2, 2.3, TE1.2, and 2.1.

Between the coastal plain and Site 605, in the Baltimore Canyon Trough, the sequence record is incomplete because an unconformity separates the upper Campanian from the lower Eocene. This unconformity, named the East Coast Sequential Unconformity (ECSU), developed through sequential submarine erosion events which began in latest Campanian time and ended in earliest Eocene time. This erosion resulted from a cool, southward-flowing current system that alternately scoured (1) middle shelf to upper slope environments during high stands of sea level, and (2) various slope environments during low stands of sea level. This mechanism of erosion is distinct from and possibly in addition to other erosive mechanisms operating along the margin at this time, such as subaerial exposure along the inner shelf or canyon cutting along the slope.
\end{abstract}

\section{INTRODUCTION}

Site 605 is located on the upper continental rise 156 km ( $97 \mathrm{mi}$.) southeast of Atlantic City, New Jersey (Fig. 1). The hole was spudded in $2194 \mathrm{~m}$ of water, washed to $154 \mathrm{~m}$ sub-bottom depth, then continuously cored to $816.7 \mathrm{~m}$. The site, which is near U.S. Geological Survey multichannel line 25, the baseline for the "New Jersey transect," was positioned to provide data which would link DSDP holes with outcrops, existing wells on land, and wells along the continental shelf (Fig. 2). The objectives were to obtain a better understanding of (1) the relationship between coastal plain, shelf, slope and rise deposits; (2) the origin of apparent unconformities visible on seismic profiles; and (3) the history of sea-level fluctuations. The nearly complete middle Maestrichtian to middle Eocene section is divided into lithologic Units II, III, IV, and V (Figs. 3, 4). Unit II consists of $153 \mathrm{~m}$ of middle Eocene biosiliceous, nannofossil chalk rich in foraminifers, radiolarians, and diatoms (van Hinte, et al., 1985). Unit III contains $214 \mathrm{~m}$ of lower Eocene, greenish gray, nannofossil limestone with varying amounts of foraminifers and calcified radiolarians. Upper Paleocene, dark greenish gray, clayey nannofossil-foraminiferal limestone (marl) comprises $176 \mathrm{~m}$ of Unit IV. Unit V, a lower Paleocene to middle Maestrichtian, olive gray, clayey, nannofossil foraminiferal limestone, is $77 \mathrm{~m}$ thick.

Site 605 lies directly offshore of the coastal plain of New Jersey, where a well-known Maestrichtian to middle

\footnotetext{
${ }^{1}$ van Hinte, J. E., Wise, S. W., Jr., et al., Init. Repts. DSDP, 93: Washington (U.S. Govt, Printing Office).

2 Addresses: (Olsson) Dept. of Geological Sciences, Rutgers University, New Brunswick, NJ 08903; (Wise) Dept. of Geology, Florida State University, Tallahassee, FL 32306-3026.
}

Eocene section is present (Olsson, 1980). In the coastal plain, deposition of sands, silts, and clays occurred for the most part in shelf environments. Glauconite is ubiquitious and is extremely abundant in some units. The entire section consists of alternating transgressive and regressive formations for which much biostratigraphic and paleoenvironmental data are available (Charletta, 1980; Olsson, 1980; Olsson and Nyong, 1984). Most of these biostratigraphic data are based on planktonic foraminifers, little on calcareous nannofossils. Thus it has not been possible to make comparisons of Tertiary nannofossil data between the New Jersey onshore and offshore sections. Futhermore, without nannofossil data it is difficult to constrain the chronostratigraphic extent of hiatuses in the coastal plain and at Site 605. In order to alleviate the lack of nannofossil data in the coastal plain, Paleogene well samples from the New Jersey coastal plain were studied for their nannofossil content, and range charts were prepared (Jiang and Wise, this volume). As a consequence, it is now possible to make a fairly detailed comparison of Site 605 with the coastal plain and, thereby to provide a better understanding of the geologic history of this segment of the western Atlantic passive margin.

\section{STRATIGRAPHY AND BIOSTRATIGRAPHY}

The stratigraphic record at Site 605 contains an exceptionally complete middle Eocene to lower upper Maestrichtian section (van Hinte et al., 1985). Oceanic reflector Horizons $\mathrm{A}^{\mathrm{c}}$ and $\mathrm{A}^{*}($ ?) were correlated by nannofossil biostratigraphy with the time scale of Berggren et al. (1985) as $49.5 \mathrm{Ma}$ and $60 \mathrm{Ma}$, respectively, thus confirming the prediction of Vail et al. (1980). The correlation of reflector Horizon A* into Site 605 from Site 387, 


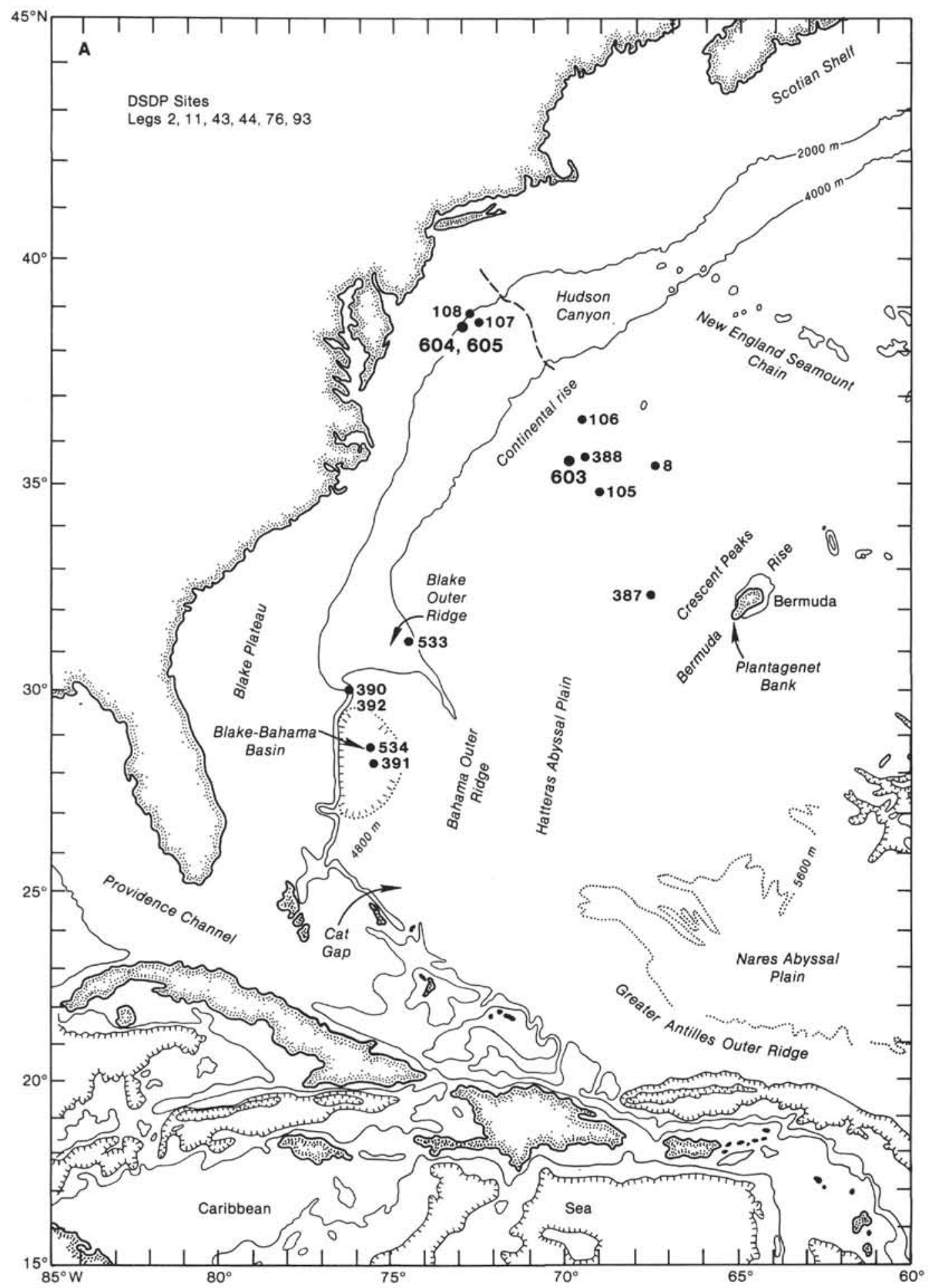

Figure 1. A. Location of Leg 93 sites. B. Geologic map of outcropping of Tertiary strata on New Jersey slope (after Robb et al., 1981) showing location of Site 605 and U.S.G.S. line 25 (dotted line).

where it was defined (Tucholke, 1979), is regarded here as tenuous. At Site 387 Horizon $\mathrm{A}^{*}$ is associated with an uppermost Maestrichtian marly chalk. Since this reflector has not been traced on seismic lines to Site 605 , we refer to the strong lower Paleocene reflector here as $A^{*}($ ?) (Fig. 2). The record at Site 605 has partially fulfilled the objective of the "New Jersey transect" of the
Deep Sea Drilling Project, which is to develop a dipwise transect of a passive margin from the coastal plain to the abyssal plain. Such a transect would help document the presence, nature, and age of unconformities, their relationship to seismic discontinuities, and their relationships to sea-level fluctuations. The closest area with a well-known stratigraphic record that can be compared 


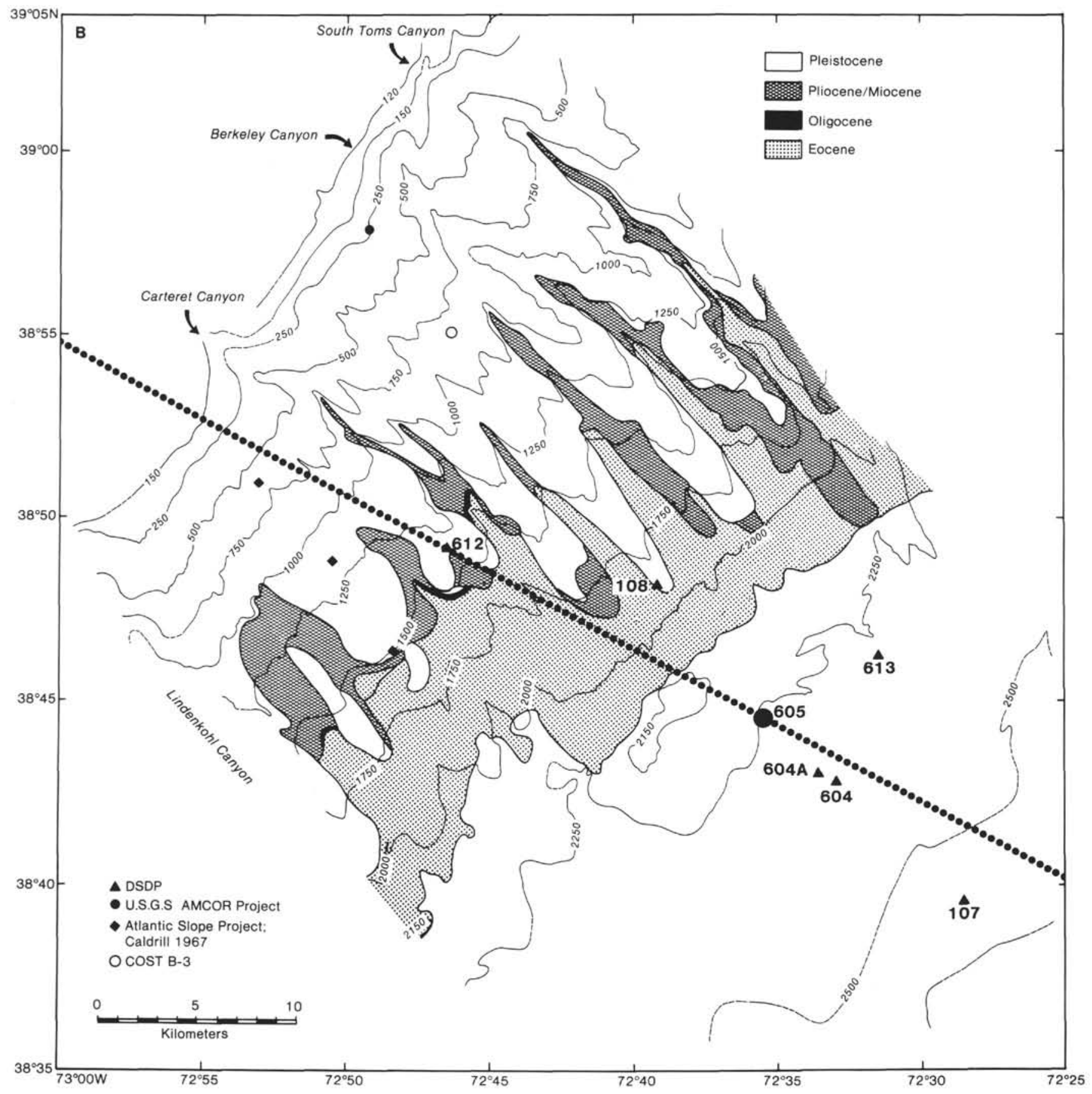

Figure 1 (continued).

to Site 605 is the coastal plain of New Jersey. In the coastal plain of New Jersey, Maestrichtian to middle Eocene formations have been dated by planktonic foraminiferal biostratigraphy (Olsson, 1964, 1969, 1980; Petters, 1977; Koch and Olsson, 1977). In order to constrain more tightly the ages of formational boundaries and unconformities in the coastal plain, nannofossil biostratigraphy has been applied (Jiang and Wise, this volume), so that a detailed comparison can be made with Site 605 .

\section{Correlations between Site 605 and New Jersey Coastal Plain}

In the coastal plain of New Jersey, the Maestrichtian to middle Eocene section consists of six depositional sequences which record sea-level events on the western Atlantic margin (Fig. 4). Each sequence begins with a transgressive lithologic unit which was deposited during a rise in sea level. The sequence ends with a regressive unit which records a shoaling of the sea at the top of the se- 


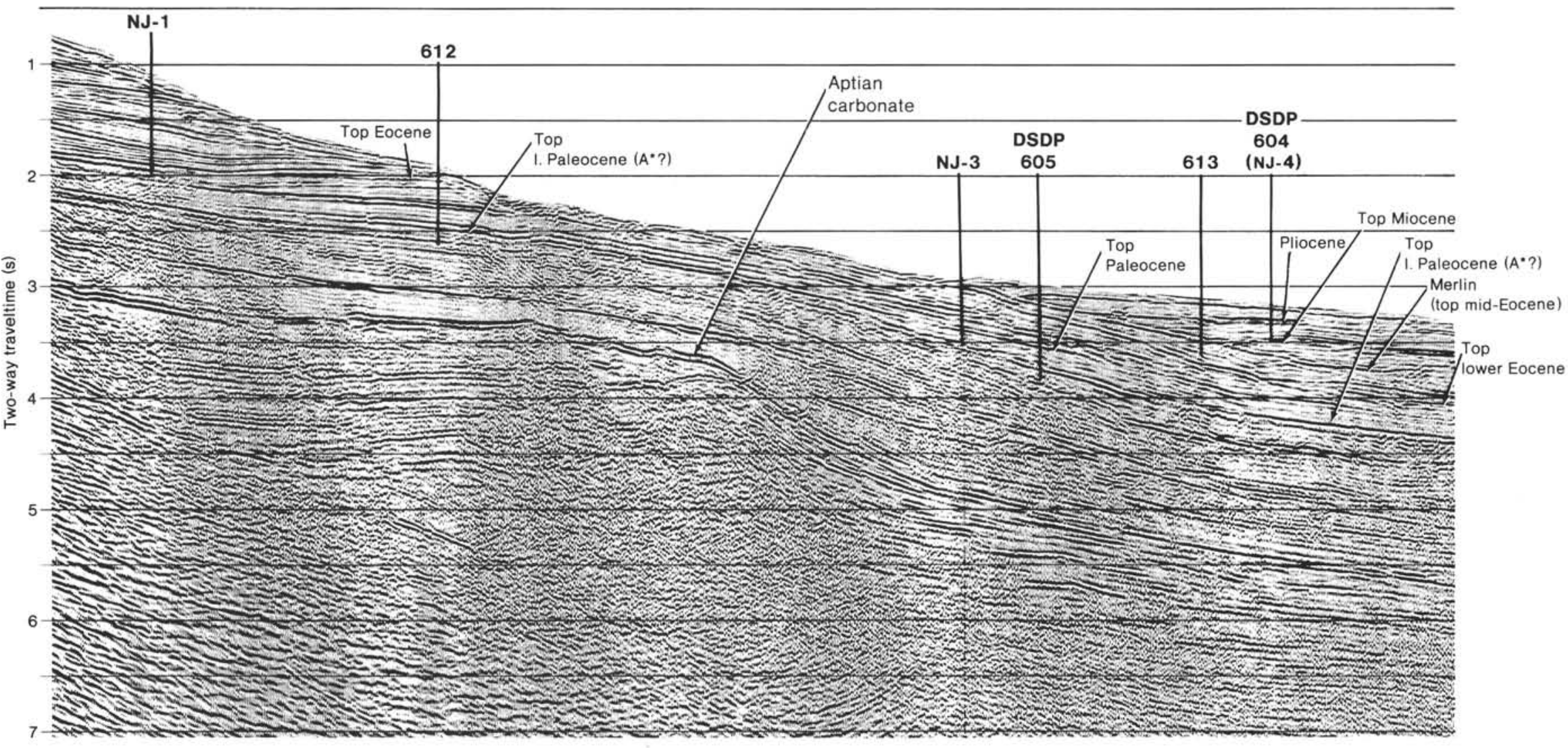




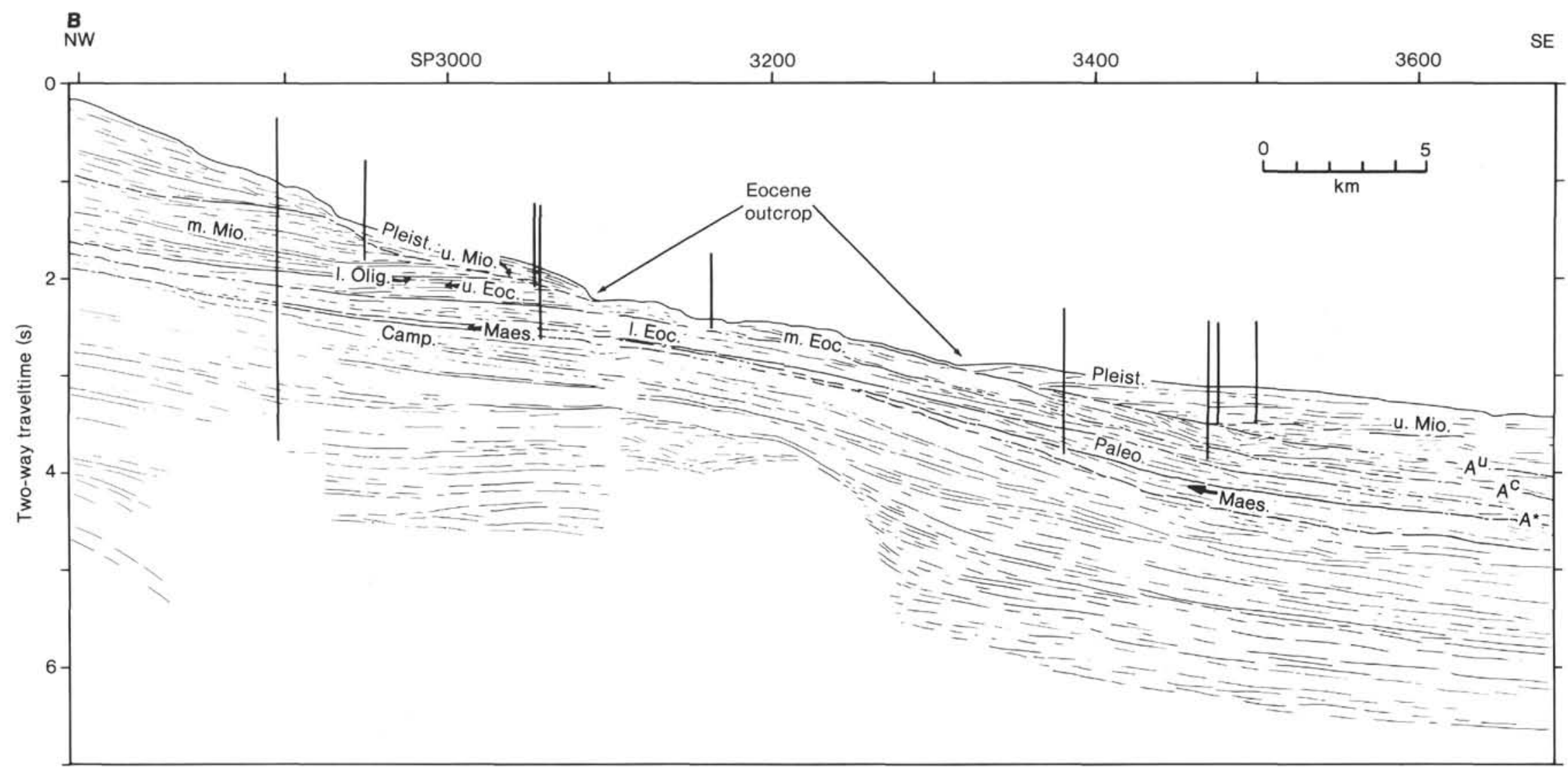

Figure 2. Original profile (A) and interpreted line drawing (B) of a segment of U.S.G.S. multichannel line 25 showing locations of Sites 605 and 612 projected onto the line. (After Poag, Watts, et al., in press, frontispiece. 


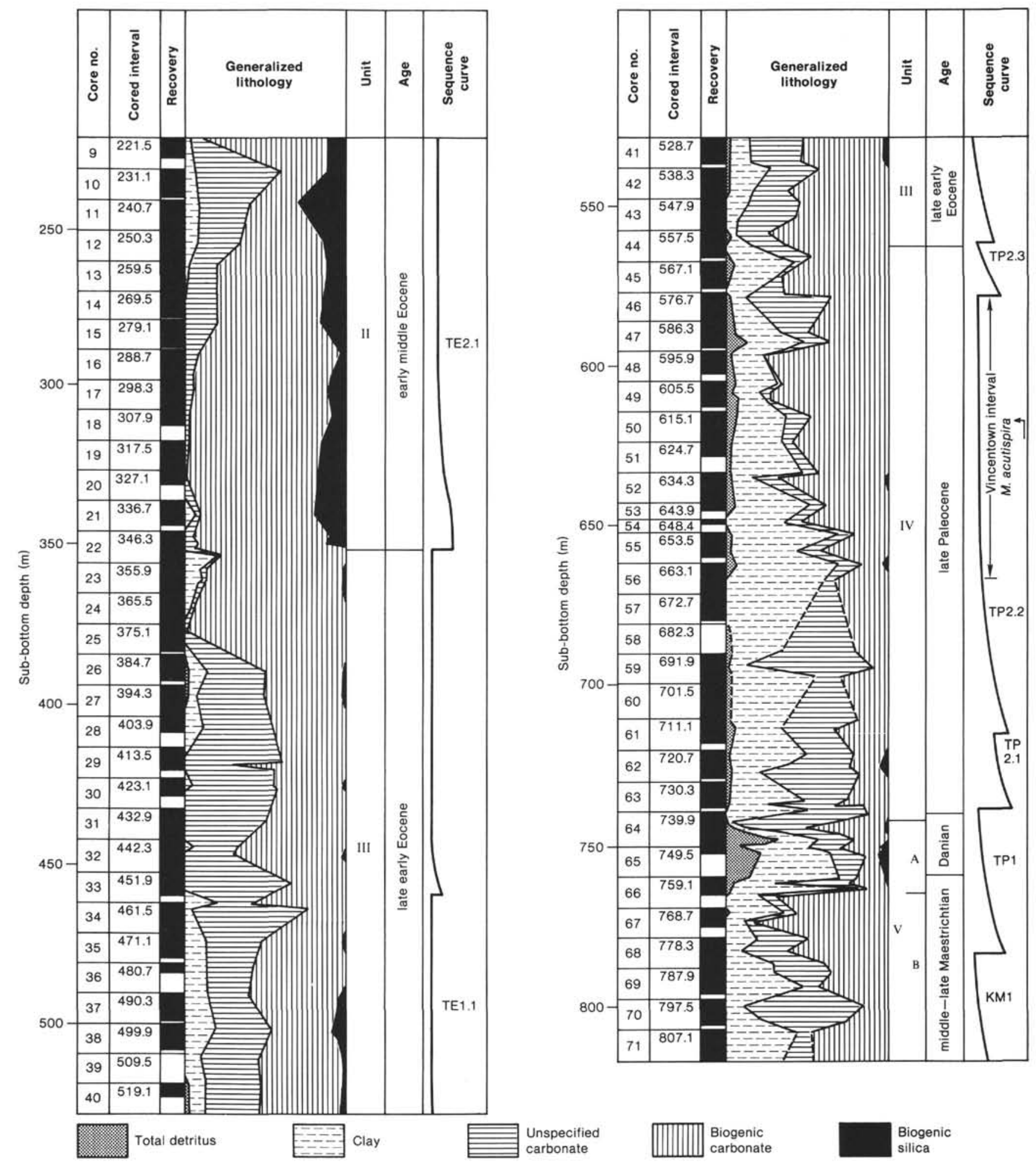

Figure 3. Lithologic log of Site 605 for the Maestrichtian to middle Eocene section. Suggested correlation of sea-level sequence curve is shown.

Note close correlation of silt-enriched interval in the upper Paleocene with coastal-plain Vincentown Formation interval.

quence. The sequences are separated by unconformities which are recognized on physical and biostratigraphic evidence (Fig. 4). The Maestrichtian section in the coastal plain consists of the Mt. Laurel-Wenonah, Navesink, Redbank-New Egypt-Tinton, and Hornerstown formations (Fig. 4).

\section{Navesink Formation (Maestrichtian)}

Site 605 terminated in the middle Maestrichtian Globotruncana stuarti Zone (Jansen and Kroon, this volume). In the coastal plain, the Navesink Formation falls within the G. stuarti and G. contusa zones (Figs. 4, 5). 


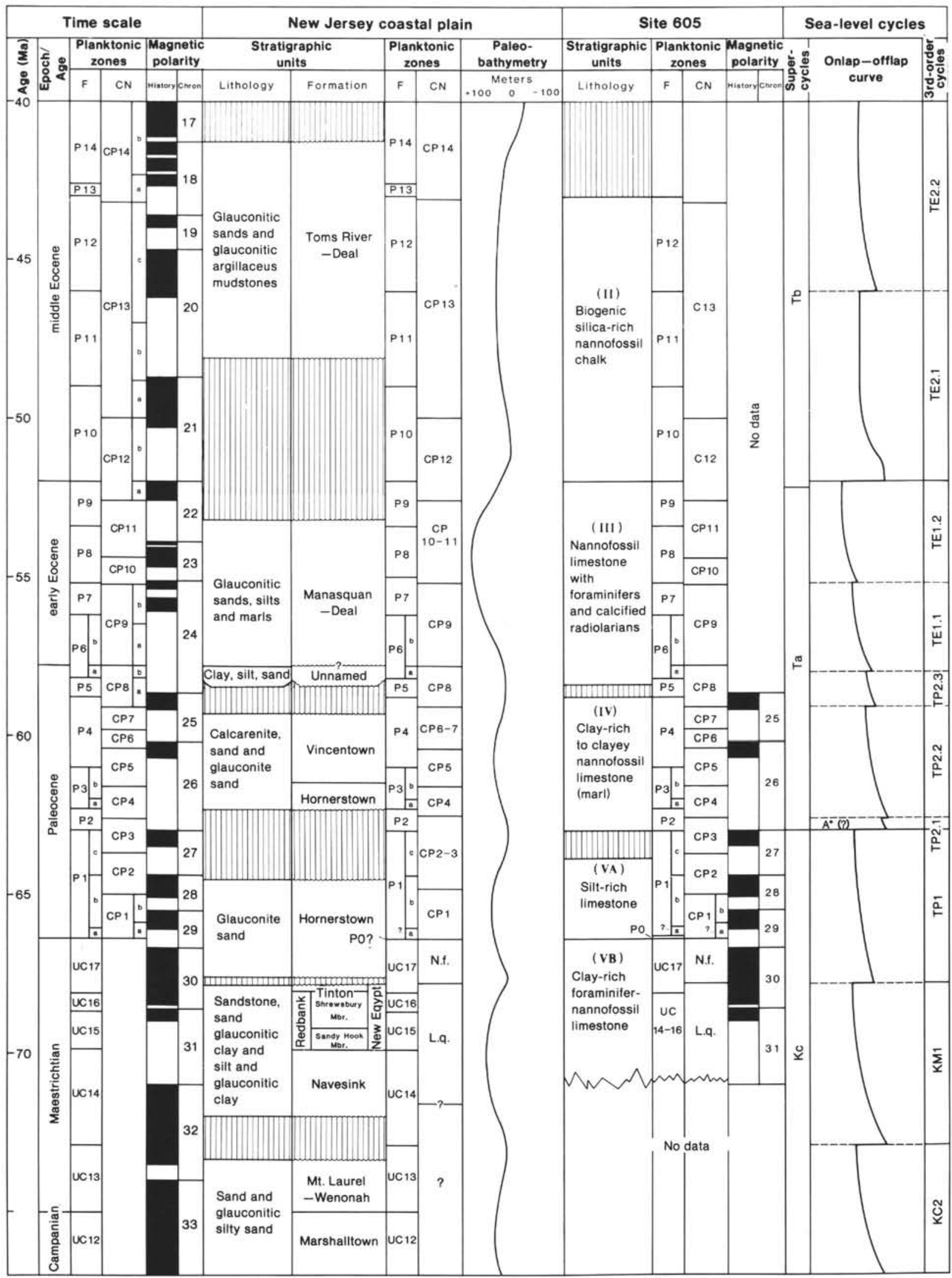

Figure 4. Comparison of New Jersey coastal plain stratigraphy, biostratigraphy, and paleobathymetry with lithostratigraphy, biostratigraphy, and magnetostratigraphy of Site 605. Magnetostratigraphy after Bruins et al. (this volume). Onlap-offlap curve for Tertiary sequences after Vail et al. (1977). Cretaceous sequences derived from New Jersey coastal plain (Olsson, 1980). N.f. = Nephrolithus frequens, L.q. = Lithraphidites quadratus. History = polarity record. 
Two useful planktonic species found at Site 605 and in the coastal plain are Hedbergella holmdelensis Olsson and $H$. monmouthensis (Olsson). Hedbergella holmdelensis ranges from near the Campanian/Maestrichtian boundary in the coastal plain into the middle Maestrichtian (Olsson, 1964). It gives rise to H. monmouthensis, which first appears in the uppermost part of the Navesink Formation above the $G$. stuarti/G. contusa zonal boundary. At Site $605 \mathrm{H}$. monmouthensis is observed in Section 605-68-1, within the Racemiguembelina fructicosa Zone, and $H$. holmdelensis is observed in Section 605-71-4, within the G. stuarti Zone. Hedbergella monmouthensis first occurs, then, somewhere between these two samples, probably near the base of the $G$. contusa Zone. Its first occurrence falls within the nannofossil Lithraphidites quadratus Zone.

\section{Redbank-New Egypt-Tinton Formations (Maestrichtian)}

The Navesink Formation is a transgressive glauconitic clay which was deposited during a Maestrichtian rise in sea level. It is the lower part of a sequence which ends with deposition of the regressive Redbank, New Egypt, and Tinton formations (Figs. 4, 5). The Redbank, an inner to middle shelf sand, is replaced downdip and along strike by the New Egypt, a shelf facies consisting of glauconitic silt and clay. The top of the sequence is capped in places by the Tinton, a glauconitic sandstone. Spheroidally weathered blocks within the Tinton Formation and a burrowed surface at the top of the New Egypt Formation indicate an unconformable contact with the overlying Hornerstown Formation. Racemiguembelina fructicosa first appears in the Shrewsbury Member of the Redbank Formation, thereby indicating that this formation extends from the $G$. contusa Zone into the $R$. fructicosa Zone (Figs. 4, 5). At Site 605 the first appearance of $R$. fructicosa occurs within the lower part of Core 69 (Jansen and Kroon, this volume). Clay-rich foraminifer-nannofossil limestone was deposited at Site 605 in lower bathyal depths during this Maestrichtian depositional sequence (Saint-Marc, this volume). Depositional and environmental changes noted in the coastal plain might be expressed at Site 605 in subtle lithologic change or in benthic foraminiferal assemblages, but this is beyond the scope of this chapter.

\section{Hornerstown Formation (Maestrichtian)}

In the coastal plain of New Jersey, nearly pure deposits of glauconite overlie the Maestrichtian sequence just described. These uppermost Maestrichtian to middle $\mathrm{Pa}$ leocene deposits are known as the Hornerstown Formation. They were deposited in two depositional sequences, but because of the very high concentrations of glauconite the two sequences cannot be separated by physical criteria. Nevertheless, biostratigraphic data show that a hiatus separates the older latest Maestrichtian to earliest Paleocene sequence from a middle Paleocene sequence. The lowermost part of the Hornerstown contains the uppermost Maestrichtian nannofossil Nephrolithus frequens Żone (Fig. 5). At Site 605 this zone lies within the upper $75 \%$ of the planktonic foraminiferal $R$. fructicosa
Zone. Abathomphalus mayaroensis, which occurs rarely at Site 605, has not been identified in the basal Hornerstown, although all of the more frequent and common species which are associated with it at Site 605 also occur in the Hornerstown. Jansen and Kroon (this volume) note that this uppermost Maestrichtian zonal species is very rare at Site 605 . Nevertheless, its total range here is the same as the more frequent $R$. fructicosa, and hence they use the $R$. fructicosa Zone as a more useful zone for biostratigraphic correlation in this region. Consequently, the lowermost part of the Hornerstown is correlated with the upper part of the worldwide A. mayaroensis Zone.

The Hornerstown Formation is a very interesting unit because it spans the Cretaceous/Tertiary boundary. In outcrops where vertebrates, molds of invertebrate megafossils (ammonites, mollusks, etc.), and dinoflagellates establish that the basal beds of the Hornerstown Formation are uppermost Cretaceous (Maestrichtian), there is no discernible physical break separating Cretaceous from Paleocene beds (Koch and Olsson, 1977). The formation is a homogeneous unit that formed in a shallow shelf environment where glauconitized fecal pellets accumulated as residual concentrations. As these beds are traced into the subsurface, they become more clayey and contain minor amounts of silt. They disappear along strike to the south where, in Delaware and Maryland, they are replaced by the Paleocene sands of the Brightseat and Aquia formations.

The lowermost Paleocene beds identified in the Hornerstown Formation are placed in the Subbotina pseudobulloides Zone (P1b). The basal Paleocene zones, the Guembelitria cretacea Zone (P0 of Smit, 1982) and the "Globigerina" eugubina Zone (P1a) have not been identified as being present in the Hornerstown Formation (Fig. 4) because the interval between P1b and the $R$. fructicosa Zone has not been thoroughly sampled. Koch and Olsson (1977) noted an unsampled interval of $10 \mathrm{ft}$. in well cores between Zone P1b and the Cretaceous. At Site 605 , a complete Cretaceous/Tertiary boundary section was believed penetrated but unfortunately the core shattered (Fig. 6) just above the boundary, and parts of the basal Paleocene were apparently lost (van Hinte et al., 1985). Smit and van Kempen (this volume) have identified P0 and P1b in Section 605-66-1, but "G." eugubina is missing.

The terminal Cretaceous extinction event of calcareous plankton is recorded at Site 605 and in the coastal plain. The Cretaceous beds of the Hornerstown Formation also contain the so-called "bone bed" (Richards and Gallagher, 1974), a concentration of various marine vertebrate and invertebrate species. The "bone bed" records the terminal Cretaceous extinction event of the marine vertebrates and invertebrates that died out simultaneously with the planktonic foraminifers and calcareous nannofossils.

The Maestrichtian and lower Paleocene section at Site 605 has been placed in lithostratigraphic Unit V, an olive gray, clayey, nannofossil-foraminiferal limestone which becomes silty in its upper part (van Hinte et al., 1985). The upper part of this unit contains the Subbotina trinidad- 


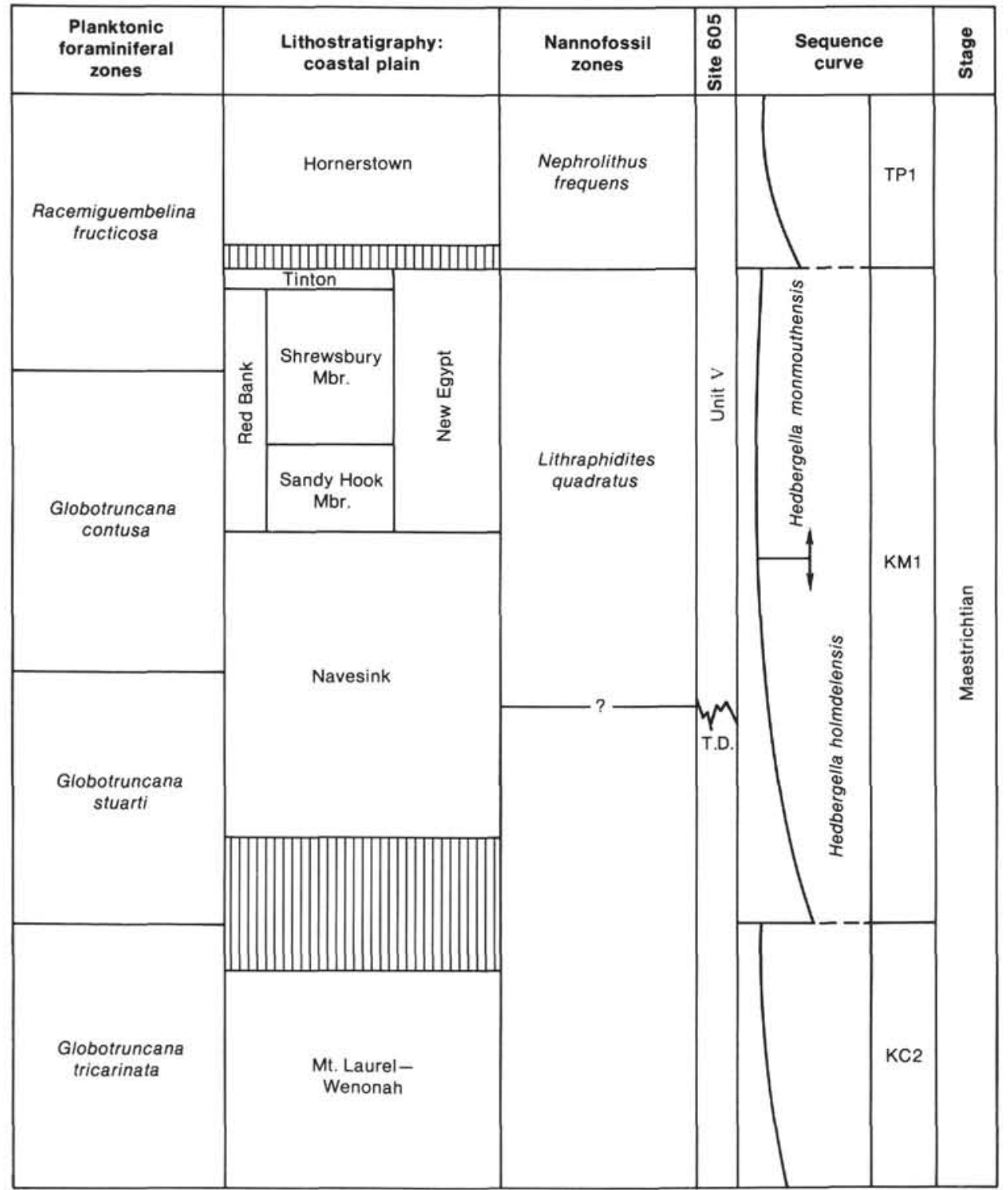

Figure 5. Correlation of Cretaceous New Jersey coastal plain formations with Site 605. Planktonic foraminiferal zones as used by Jansen and Kroon (this volume).

ensis (P1c) Zone (Saint-Marc, this volume). The Morozovella uncinata Zone (P2) is poorly defined, and the $M$. angulata Zone (P3a) is not identified. Paleocene calcareous nannofossil zones in Unit V include Cruciplacolithus tenuis (CP1b) and Chiasmolithus danicus (CP2). A hiatus separates Unit V from Unit IV; the upper part of $\mathrm{CP} 2$ and the lower part of the overlying Ellipsolithus macellus Zone (CP3) is missing (Lang and Wise, this volume). Oceanic reflector $\mathrm{A}^{*}($ ?) has been identified with the top of Unit V (van Hinte et al., 1985) and therefore it is associated with this lower Paleocene hiatus.

In the coastal plain a hiatus is also present in the Hornerstown between the early and upper Paleocene beds (Fig. 4). The M. uncinata Zone (P2) and the upper part of the $S$. trinidadensis Zone (P1c) are missing. Most of the nannofossil $\mathrm{CP} 2$ and $\mathrm{CP} 3$ zones are missing. The unconformity and hiatus associated with oceanic reflector $\mathrm{A}^{*}(?)$ can therefore be traced from Site 605 into the coastal plain. The reflector marks the top of depositional sequence TP1 of Vail and others (1977, 1980).

\section{Vincentown Formation (upper Paleocene)}

In the coastal plain, the upper Paleocene depositional sequence includes the upper part of the Hornerstown Formation and Vincentown Formation, an inner shelf calcareous sand which was deposited during the shoaling phase of the sequence (Fig. 4). The Hornerstown Formation contains the Morozovella angulata Zone (P3a) and the lower part of the Planorotalites pusilla pusilla Zone (P3b). The Vincentown falls within the upper part of $\mathrm{P} 3 \mathrm{~b}$ and the P. pseudomenardii Zone (P4). Nannofossil zones $\mathrm{CP} 4$ through $\mathrm{CP} 7$ are contained within the 

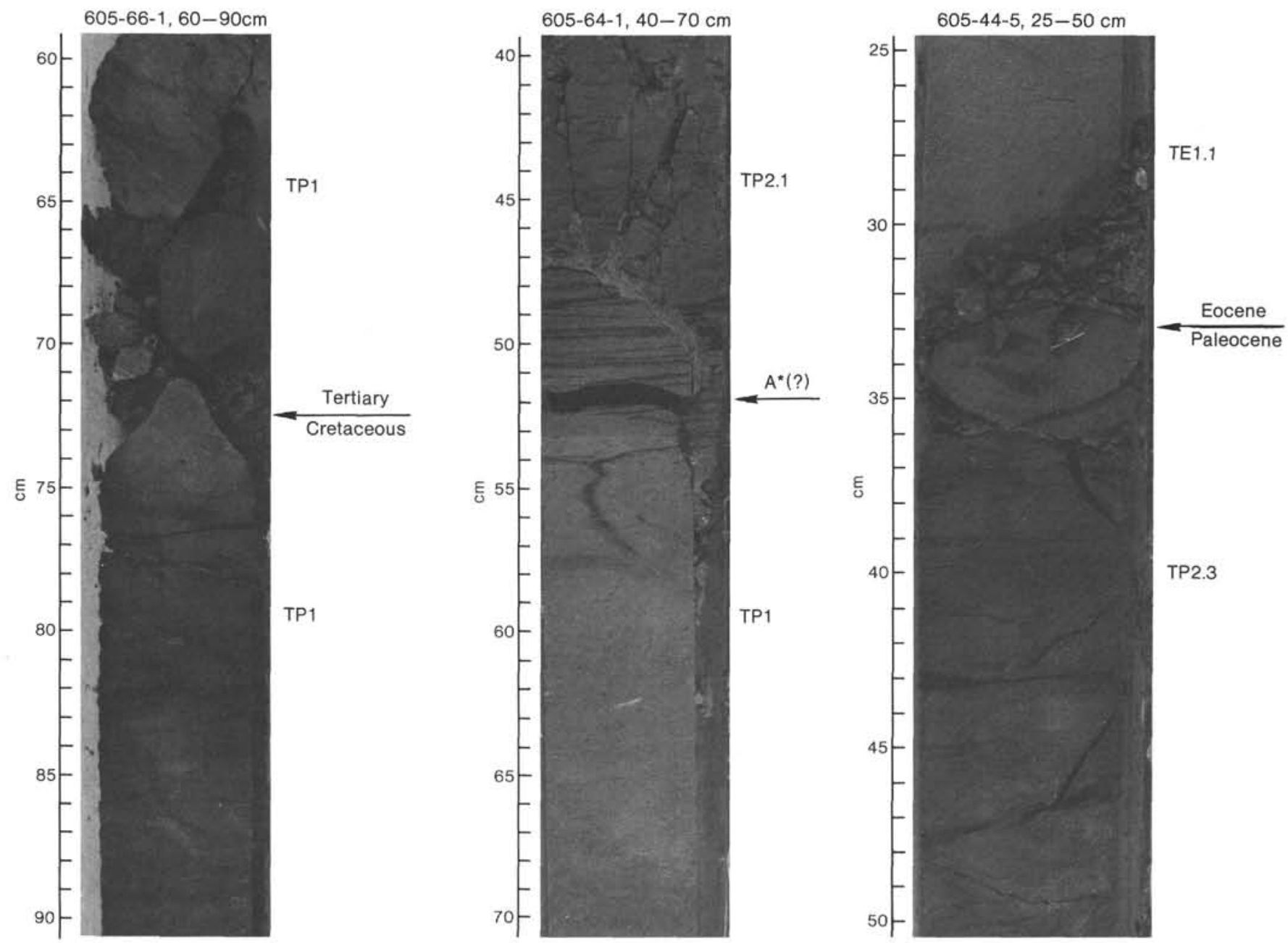

Figure 6. Sections 605-66-1, 605-64-1, and 605-44-5, showing breaks associated with the Cretaceous/Tertiary boundary, seismic reflector A*(?), and the Paleocene/Eocene boundary, respectively.

sequence. An unconformity, where the lower part of the $M$. velascoensis Zone is missing, separates the Vincentown from the sequence above.

At Site 605, P3b and P4 are well developed. A hiatus is suggested between P4 and P5 (see Saint-Marc, this volume). A very useful species for correlation within Zone P4 is Morozovella acutispira, which becomes extinct in the middle part of the zone (Petters and Olsson, 1979). It is a very common to abundant species in the coastal plain and it exhibits an abrupt extinction within the lower part of the Vincentown Formation. Examination of samples from Site 605 show that here too it is very common. Its extinction level falls within Core 49. This level apparently coincides with the extinction of $M$. conicotruncana, which is a less common species in 605 and in the coastal plain.

The upper Paleocene at Site 605 is placed in lithostratigraphic Unit IV, a dark greenish gray, clayey, nannofossil-foraminiferal limestone (van Hinte et al., 1985). Minor amounts of quartzose silt in Cores 46 to 56 correlate with the Vincentown sand. In the subsurface of the coastal plain, the Vincentown grades into a quartzose silt facies. This suggests that some of the silt was depos- ited as far out as the 605 site. Unit IV and its correlative Hornerstown and Vincentown formations are depositional sequence TP2.2 of Vail and others (1977).

\section{Upper Paleocene-Lower Eocene Formations}

In the coastal plain subsurface a gray clay, silt, and sand unit separates the Vincentown and the Manasquan formations. This unit is first identified in this study as distinct from the Vincentown Formation, with which it is included on physical logs. The unit is barren of nannofossils but contains rare foraminifers that suggest an upper Morozovella velascoensis Zone (P6a). A hiatus with $\mathrm{P} 5$ and possibly an upper portion of $\mathrm{P} 4$ missing is suggested (Fig. 4). A sharp change in lithology in the overlying Manasquan Formation may indicate an unconformable contact. The uppermost Paleocene unit is correlated with depositional sequence TP2.1 of Vail et al. (1977).

Overlying the upper Paleocene sequence in the coastal plain are the glauconitic sands, silts, and marls of the Manasquan and Deal formations (Fig. 4). These units were deposited in outer shelf to upper slope environments (Charletta, 1980; Olsson, 1980). The Deal becomes 
the dominant lithology in the subsurface of the coastal plain where it becomes increasingly clayey; it extends from the lower Eocene to the middle Eocene. It is very rich in microfossils, including foraminifers, coccoliths, dinoflagellates, and abundant siliceous microfossils (radiolarians, diatoms, sponge spicules). Both in microfossil content and in lithology the Deal is similar to lithostratigraphic Units II and III in Hole 605. The Lower Eocene part of the Deal is equivalent to Unit III (Fig. 4), which contains planktonic foraminiferal Zones P6 through CP9 and nannofossil Zones CP8 through CP11 (Fig. 4). In the coastal plain, planktonic foraminiferal Zones P6 to the basal part of P9 and nannofossil Zones $\mathrm{P} 9$ to $\mathrm{CP} 11$ are present in the lower Eocene sequence (Jiang and Wise, this volume).

The lower Eocene sequence in the coastal plain is separated from the middle Eocene by a hiatus (Fig. 4). Zones $\mathrm{P} 10$ and $\mathrm{CP} 12$ are missing, as well as parts of P9, P11, CP11, and CP13. No apparent hiatus is present at Site 605 (Applegate and Wise, this volume). Seismic reflector $\mathrm{A}^{\mathrm{c}}$, a diagenetic horizon (Tucholke, 1979), lies above the lower/middle Eocene boundary. The lower Eocene sequence is identified as depositional sequences TE1.1 and TE1.2 of Vail et al. (1977). More detailed analysis is necessary to determine whether these two sequences can be separated in the coastal plain and Hole 605.

The middle Eocene sequence in the coastal plain is less well known because it is mostly subsurface in distribution and there are relatively few wells where it has been sampled. Glauconitic sands and argillaceous mudstones were deposited in middle shelf environments. The similarity of the Deal with Unit II was noted above. The middle Eocene sequence is contained within planktonic foraminiferal Zones P11 to P14 and nannofossil Zones CP13 and CP14 (Jiang and Wise, this volume), thus establishing the equivalency of this sequence in the coastal plain and in Hole 605 (Fig. 4). This indicates that sequences TE2.1 and TE2.2 is at least partially developed here.

\section{Sequences}

This analysis shows that there is a close correlation between the depositional sequences of the coastal plain of New Jersey and Site 605 and the sequences of Vail et al. $(1977,1980)$. It further shows that seismic reflector $A^{*}($ ?) is associated with an unconformity at Site 605 and that this unconformity is also present in the coastal plain. Biostratigraphic evidence indicates that an unconformity is also present in the uppermost Paleocene. Thus it is clear that Vail sequences TP1, TP2, TE1, and TE2 are documented in this part of the western Atlantic margin (Fig. 4). The details of Upper Cretaceous sequences are not shown by Vail and others. Nevertheless, in this chapter three sequences are designated: two Campanian sequences, $\mathrm{KC} 1$ and $\mathrm{KC} 2$; and one Maestrichtian, $\mathrm{KM} 1$. Maestrichtian sequence KM1 is correlated with Site 605 .

In the New Jersey coastal plain all of the sequences, except TP1, begin with transgressive glauconitic clays and silts and end with regressive sands. Although in
New Jersey TP1 does not contain a regressive sand, farther south in the coastal plain of Maryland and Delaware the clayey, silty sands of the Brightseat Formation are present in the upper part of the sequence.

At Site 605 , lithologic changes that possibly correlate with the coastal plain sequences are evident. Sequence KM1 (only the upper part is present) has a fairly high clay content. A reduction in clay content occurs at the beginning of TP1 (Fig. 3). Low clay and high carbonate content are associated with the lower part of sequence TP1 and silt-rich limestones with the upper part (Fig. 3). The high terrigenous as well as increased glauconite content of the Danian sediments of Site 605 can be explained in several ways (van Hinte et al., 1985). These include effects of a terminal Cretaceous meteorite impact, a drop in sea level, normal current activity, and outbuilding of a local delta. Although the silt content is high in this interval, it should be pointed out that silt intervals also occur in the upper Paleocene section of Site 605. In the upper Paleocene in sequence TP2.2, the interval with increased silt content correlates closely with the Vincentown Formation in New Jersey and the Aquia Formation in Maryland, Virginia, and Delaware. These sandy units become more silty as they are traced into the coastal plain subsurface (Hansen, 1974; Olsson, 1980). Thus, it would appear that the source of terrigeneous silt at Site 605 in the upper Paleocene is from the coastal plain, and that the silt was transported to Site 605 during the regressive phase of TP2.2. The high silt content in TP1 at Site 605 , it would appear, is related in a similar way to the regressive Brightseat Formation. Other silt intervals (Fig. 3) in the Paleocene of Site 605 possibly correlate with sequences TP2.1 and TP2.3.

Silt is present in only minor amounts in the lower Eocene of Site 605 and is absent in the middle Eocene. The general lack of silt during the early Eocene may be due to a higher sea level at this time (Charletta, 1980; Miller and Katz, in press; Fig. 4) which reduced the amount of silt that could be transported to Site 605 . The near absence of braarudosphaerids in nannofossil Zones CP10 and 11 (Applegate and Wise, this volume) also suggest a diminution of nearshore influences because of high sea levels.

During coring at Site 605 , the core broke up at three horizons: at the Paleocene/Eocene boundary, at Horizon $\mathrm{A}^{*}($ ?), and at the Cretaceous/Tertiary boundary (Fig. 6). The break at the Paleocene/Eocene boundary is associated with a lithologic change from a dark greenish gray, clay-rich, nannofossil limestone in the Paleocene to a pale greenish gray to yellowish grayish green, foraminifer-bearing, clay-rich nannofossil limestone in the lower Eocene. This lithologic contrast is also evident in the subsurface of the New Jersey coastal plain, where dark gray glauconitic clays and silts in the Paleocene give way to light yellowish gray clays, silts, and fine sands of the lower Eocene.

The break at Horizon $A^{*}($ ?) (Fig. 6) falls at a change in lithology from a dark greenish gray, silt-rich to clayey, foraminiferal-nannofossil limestone below $A^{*}($ ?) to a light gray, clayey, nannofossil limestone above. In the 
coastal plain subsurface, dark greenish gray glauconitic clays occur above and below the unconformity correlated with Horizon $A^{*}(?)$.

The break at the Cretaceous/Tertiary boundary (Fig. 6) falls within lithologic Unit VI. The silt content increases above the boundary, although the break is most probably related to the terminal Cretaceous mass extinction level and possibly to a boundary clay that may have washed away during coring (van Hinte, et al., 1985).

As noted by Applegate and Wise (this volume) there is no visually apparent lithologic break between the middle Eocene (Unit II) and the lower Eocene (Unit III). The boundary is defined by a sharp decrease in biogenic silica in the lower Eocene immediately below the middle Eocene. In the coastal plain subsurface of New Jersey, as noted above, both the middle and lower Eocene are very similar lithologically and are placed in one lithologic unit, the Deal Formation. The Deal contains abundant foraminifers and coccoliths, and varying amounts of siliceous microfossils which include radiolarians, diatoms, and sponge spicules.

In summary, a comparison of Site 605 and the coastal plain of New Jersey shows that depositional sequences recognized in the coastal plain correlate closely with Site 605. Unconformities in the coastal plain correlate with unconformities at Site 605; one in particular correlates with reflector Horizon $\mathrm{A}^{*}($ ?). In turn, the depositional sequences of Vail and others (1977) for the Paleocene and the early and middle Eocene are confirmed in this area. Some close lithologic similarities are also evident between Site 605 and the New Jersey coastal plain. This confirmation shows that the sea-level cycles established by Vail and others affected the western Atlantic margin from Site 605 into the coastal plain. Rises and falls of sea level were synchronous between the coastal plain and Site 605 .

\section{THE EAST COAST SEQUENTIAL UNCONFORMITY (ECSU)}

Wells drilled in the Baltimore Canyon Trough, however, do not contain the nearly complete record that is present at Site 605 and in the coastal plain. A large Maestrichtian and Paleocene hiatus is present in the Baltimore Canyon Trough (Olsson, 1980; Poag, 1980). Up to six depositional sequences in the Maestrichtian and $\mathrm{Pa}-$ leocene are not preserved there. These sequences cannot be missing because of a single erosional event; the record in the coastal plain and at Site 605 shows that this is not possible. Furthermore, U.S.G.S. seismic line 25 shows distinct pinching out of Maestrichtian and Paleocene units (Poag and Schlee, 1984; Mountain and Tucholke, 1985). Consequently, an alternate explanation is required.

Between the coastal plain and Site 605 in the Baltimore Canyon Trough the COST B-2 and B-3 wells and all exploration wells have encountered a large unconformity separating lower Eocene strata from Campanian to lower Maestrichtian strata (Fig. 7). In some places, upper Paleocene beds are present. Drilling at Site 612 also encountered this unconformity (Poag, Watts, et al., in press; Thorne and Watts, 1984). This unconformity is not unique to the Baltimore Canyon Trough. It occurs along the western Atlantic margin from at least the Southeast Georgia Embayment to the Grand Banks (Fig. 8). In general, erosion began sometime during the Campanian and ended in the early Eocene. In some cases the hiatus of the unconformity has been enlarged by local tectonics (principally salt diapirs and igneous intrusions).

Site 384 (Fig. 8), which is located on the southeast Newfoundland Ridge adjacent to the Grand Banks in $4000 \mathrm{~m}$ water depth, is similar to Site 605 in that it contains a nearly complete Maestrichtian to Eocene record (Figs. 7, 8). Between Site 384 and Adolphus D-50 (Fig. 8) which also has a nearly complete Maestrichtian to Eocene record, an Eocene to Campanian hiatus is present (Fig. 8). The extent of the hiatus varies from small to large in the Scotian Shelf and the Georges Bank. In the Southeast Georgia Embayment, a middle Paleocene to middle Maestrichtian hiatus is present.

The record in the coastal plain shows that the western Atlantic margin experienced numerous sea-level rises and falls (Fig. 8). Furthermore, comparison of the Site 605 stratigraphic record with that for the coastal plain (Fig. 4) demonstrates a close agreement with the sea-level cycles of Vail and others (1977). It is apparent, therefore, that the large hiatus along the western Atlantic margin is not due to a single event, but must be a result of multiple events which led sequentially to the hiatus. We, therefore, refer to this unconformity as the East Coast Sequential Unconformity (ECSU). We believe that this unconformity was caused largely by submarine erosion by a major current system flowing roughly parallel to the margin. The area affected by this erosion extends from upper slope to middle shelf paleoenvironments. At the beginning of a cycle, as sea level rises, the current system shifts landward over upper slope to middle shelf environments, scouring the sea bottom (Fig. 9). Deposition here is largely nonexistent, and large parts of the bottom are subjected to erosion. Deposition occurs landward of this zone in the coastal plain and seaward on the lower slope to abyssal plain. Toward the end of each cycle, regression occurs in the coastal plain. At the end of each cycle, as sea level falls, subaerial erosion occurs in the coastal plain and the current system shifts seaward and scours upper slope environments (Fig. 9). During subsequent cycles the process is repeated; this leads to a sequence of unconformities, the ECSU.

The ECSU current system is envisioned as being similar in nature and behavior to the modern Gulf Stream. Pinet and Popenoe (1985) interpret unconformities in seismic reflection records of the Blake Plateau as due to scour by the ancestral Gulf Stream. Buried channeled topography in the Neogene record indicates that during high stands of sea level, the Gulf Stream shifted landward over the Blake Plateau and the Florida Hatteras Slope, scouring submarine channels. During times of lower sea level, the Gulf Stream shifted its position seaward, eroding the outer part of the Blake Plateau and the adjacent continental slope. Shifts in the position of the current axis involved several hundred kilometers of horizontal displacement. Pinet and Popenoe envision a vigorous and persistent Gulf Stream circulation initiated 


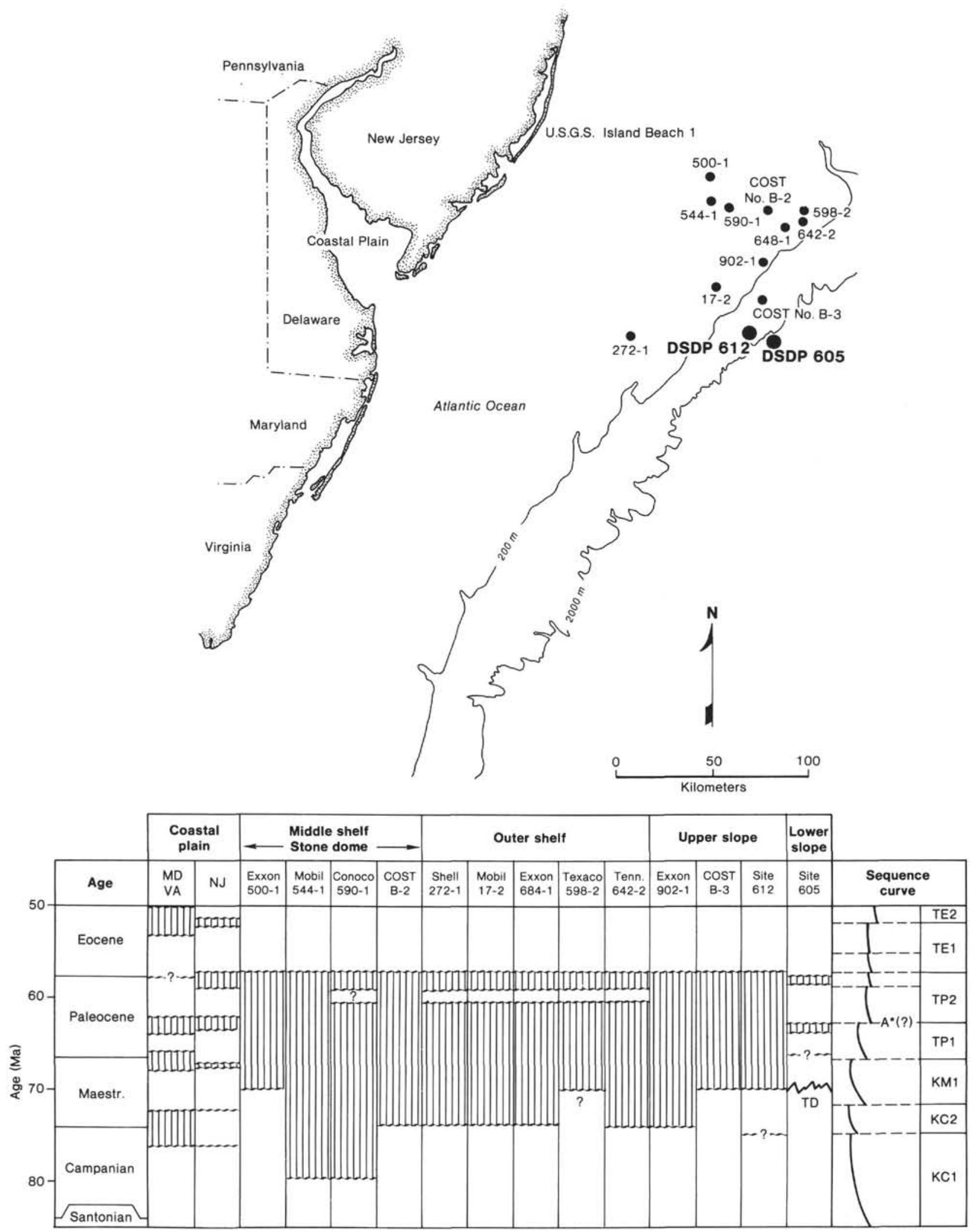

Figure 7. Chart showing the extent of the East Coast Sequential Unconformity (ECSU) in the Baltimore Canyon Trough. Data for exploration wells in Baltimore Canyon Trough from open file reports of Minerals Management Service. Data for the Maryland and Virginia coastal plain from Hazel and others (1984). Data for Site 612 from Watts and Thorne (1984). 
R. K. OLSSON, S. W. WISE, JR.

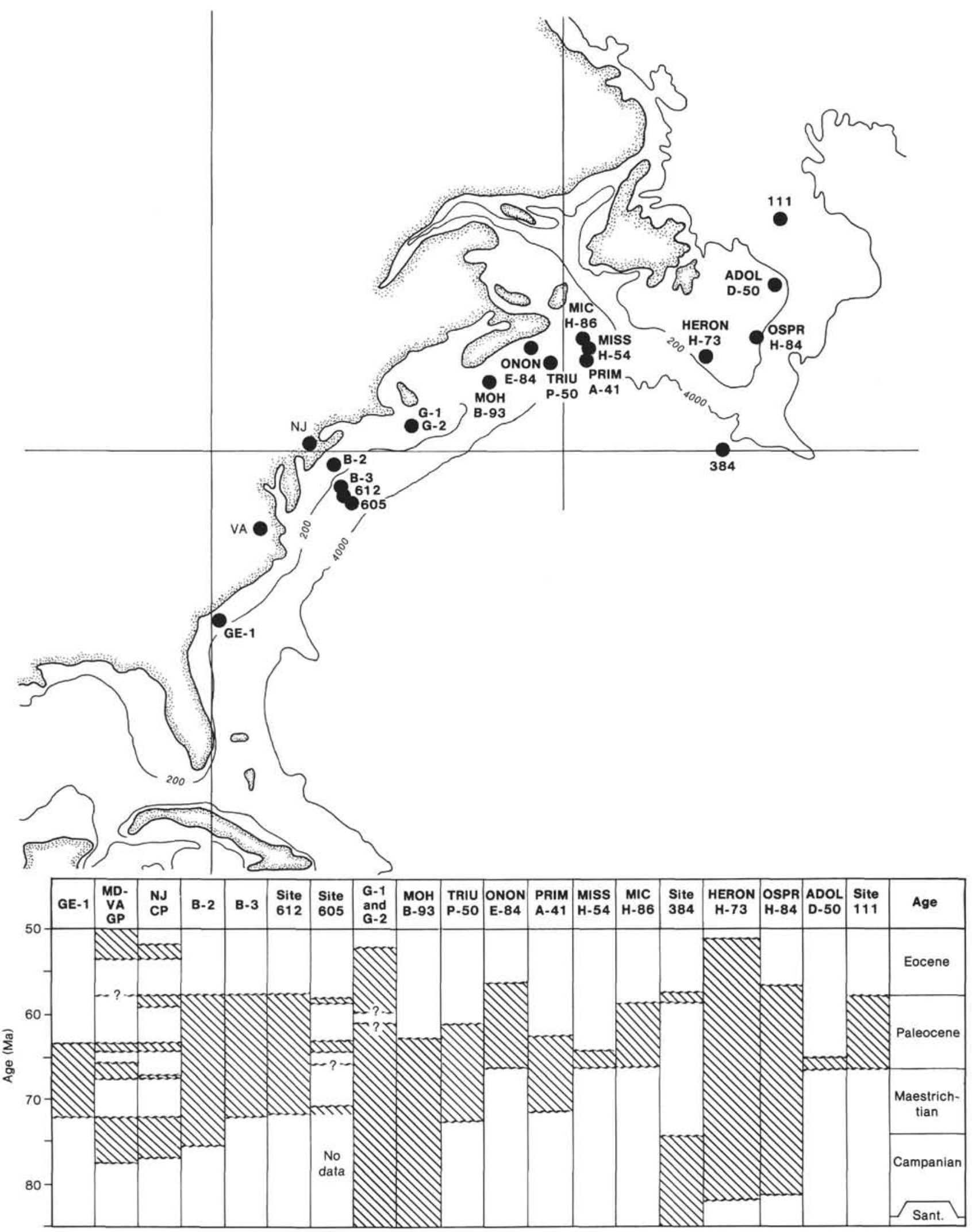

Figure 8. Chart showing the extent of the East Coast Sequential Unconformity (ECSU) along the western Atlantic margin. Data from Canadian shelf wells from Doeven (1983). $\mathrm{MOH}=$ Mohawk B-93, TRIU $=$ Triumph P-50, ONON = Onondaga E-84, PRIM = Primrose A-41, MISS $=$ Missisauga H-54, MIC $=$ Mic Mac H-86, HERON $=$ Heron H-73, OSPR $=$ Osprey H-84, ADOL = Adolphys D-50; B-2, B-3, $\mathrm{G}-1, \mathrm{G}-2, \mathrm{GE}-1,=$ COST wells. 


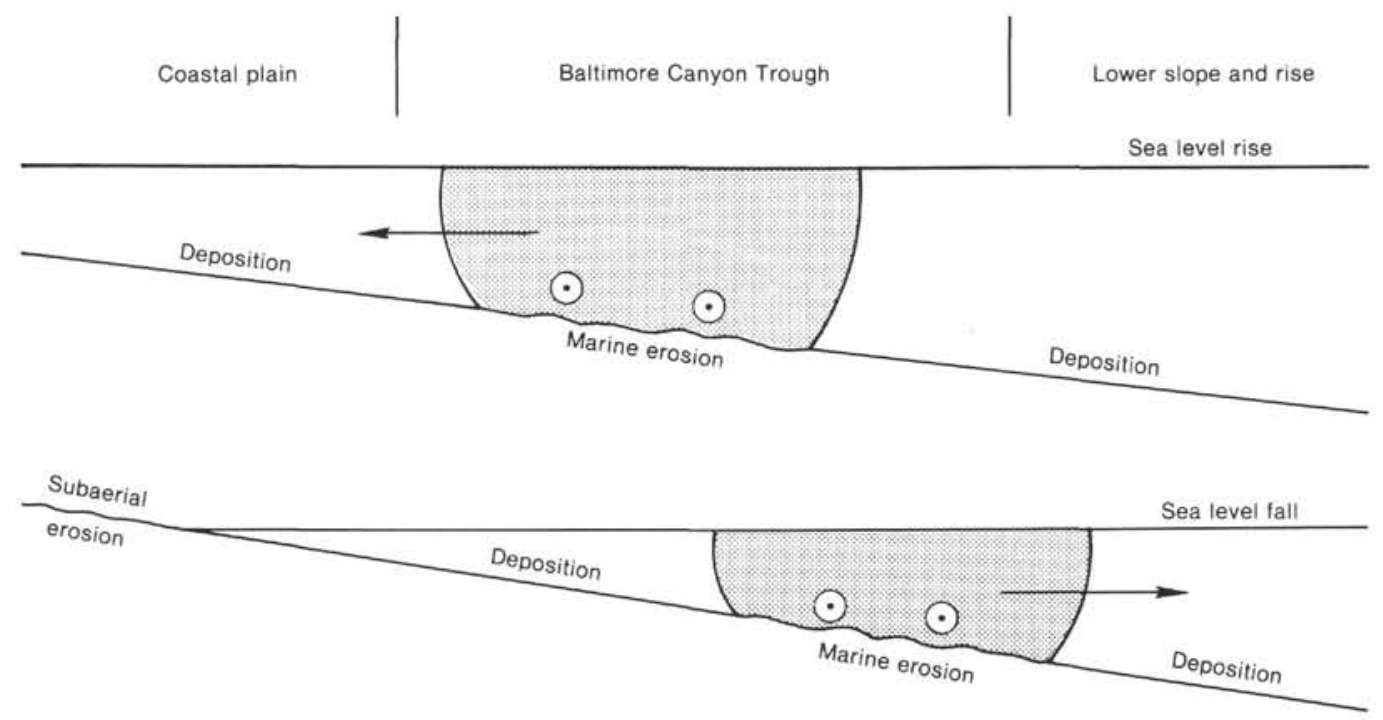

Figure 9. Model for the erosion of the ECSU as inferred from the stratigraphic record of the western Atlantic margin. Circled dots indicate current activity.

during early Tertiary time over the Blake Plateau, which led to a thin, discontinuous record of Cenozoic deposits replete with unconformities. They also envision that before Gulf Stream circulation began, waters from the Gulf of Mexico began flowing into the Atlantic during Campanian time across southern Georgia and northern Florida, through the so-called Suwannee Strait. As this current entered deeper water over the western edge of the Blake Plateau basin it deposited its sediment load, thereby building up a thick depositional mound.

Tucholke and Mountain (1979) and Mountain and Tucholke (1975) also recognize submarine erosion as a major factor in shaping the stratigraphic record in the continental rise and slope of the western Atlantic margin during the Oligocene. Abyssal current erosion occurs on the rise and lower slope during general sea-level high stand, whereas during general low stand shelf-slope erosion occurred.

The ECSU has the characteristics of major submarine erosion controlled by sea-level fluctuations. The discontinuous record of the Maestrichtian and the Paleocene supports the idea of a patchy stratigraphic record left by episodes of submarine erosion. The Maestrichtian-Paleocene interval of erosion indicates that a powerful current system operated along upper slope to middle shelf environments along the western Atlantic margin.

The Paleocene section of Site 605 is about five times thicker than that of the coastal plain, $200 \mathrm{~m}$ at Site 605 versus about $42 \mathrm{~m}$ in the coastal plain. Sedimentation rates of Paleocene depositional sequences at Site 605 are up to five times greater than in the coastal plain (Fig. 10). The higher sedimentation rates at Site 605 suggest that sediment scoured from the shelf and upper slope regions was transported downslope and accumulated on the lower slope, rise, and elsewhere. As noted previously, the quartzose silt in the Paleocene section at Site 605 can be correlated with sand and silt formations in the coastal plain. This shows that, in the Paleocene, silt and clay were transported from shelf environments to slope environments. The abundance of ichnofabrics in the Maestrichtian and Paleocene of Site 605 (Wetzel, this volume) might be explained by increased nutrients transported with these sediments. Careful study of seismic lines is needed to identify channels or canyons that may have funneled sediments from the shelf down the slope. Also facies study of Maestrichtian and Paleocene slope deposits will lead to a better understanding of the source and transportation of sediment. The ECSU current system became effective near the end of Campanian time and ceased to be effective at the beginning of Eocene time. What was the origin of this system; why did it begin, why did it end, and where did it come from?

\section{PALEOBIOGEOGRAPHY AND PALEOCEANOGRAPHY}

The paleobiogeographic affinity of Site 605 is important to determining the paleoceanography of the western Atlantic basin during formation of the ECSU. A semiquantitative study by Nyong (1984) of the distribution of planktonic foraminiferal species at a number of Deep Sea Drilling Project sites in the western Atlantic basin led him to the conclusion that during the Campanian and early Maestrichtian, the boundary between Tethyan and transitional waters lay in a southwesterly direction, roughly paralleling the western Atlantic coastline. Jansen and Kroon (this volume) noted a mixture of coldwater and warm-water species in their study of late Maestrichtian planktonic foraminifers of Site 605 . They concluded that the western North Atlantic was dominated by a warm-water gyre system, but that a cooler water mass was present in the vicinity of Site 605. Davids' (1966) analysis of Maestrichtian planktonic foraminifers from outcrops around the North Atlantic, Mediterranean, Gulf of Mexico, and Caribbean identified Globotruncana arca as a cool-water species and G. aegyptica (identified as G. gagnebini) as a warm-water species. He concluded that the western Atlantic margin lay within a temperate biogeographic province. Gradstein and Srivas- 


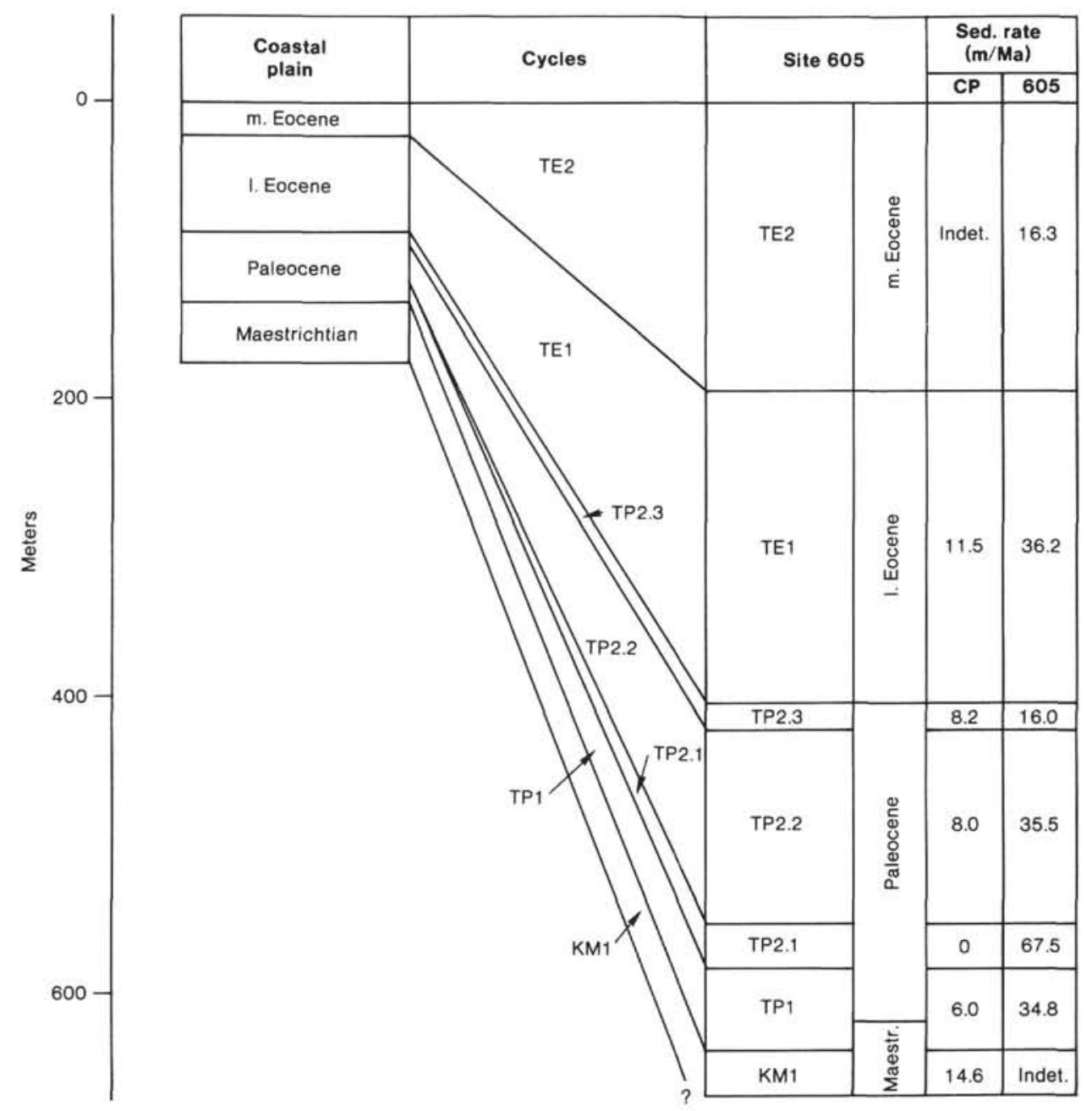

Figure 10. Comparison of the rates of accumulation between the New Jersey coastal plain and Site 605 .

tava (1980) in their study of Labrador Sea and Baffin Bay wells also regarded $G$. arca as a cool-water species.

In order to more clearly define the paleobiogeographic affinity of Site 605, data from upper Maestrichtian localities of Davids (1966) in New Jersey, the Gulf coast, and the Caribbean were analyzed by cluster and factor analysis with data from Site 605 and Site 111 in the North Atlantic (Fig. 11). The analyses were performed on two data sets, one being abundances of species of Globotruncana and the other abundances of planktonic foraminiferal genera. Eight samples from 6 localities, 16 species of Globotruncana, and 17 genera were analyzed. Q-mode cluster analysis of foraminiferal species shows that samples from Site 605 have a higher affinity with the New Jersey coastal plain and Site 111 than they do with low-latitude localities in Mexico and Trinidad (Fig. 12A). R-mode factor analysis distinguishes two groups which have paleobiogeographic importance (Fig. 12B). One group consists of two species, Globotruncana arca and $G$. contusa, which form the core of a cool-water assemblage. Globotruncana arca is the dominant species in this group; its abundance increases northward and reaches $78 \%$ in Hole $111 \mathrm{~A}$. A second group forms the core of a warm-water assemblage. It consists of G. aegy- ptica, G. falsostuarti, G. stuarti, G. stuartiformis, G. tricarinata, and G. rosetta. Globotruncana aegyptica is the dominant species in this group, reaching nearly $64 \%$ of the assemblage at the Trinidad locality. These two groups dominate the Globotruncana assemblages, usually comprising over $80 \%$ of all Globotruncana species. A third group, which includes Abathomphalus mayaroensis, is a rare cosmopolitan assemblage.

Another way of analyzing the paleobiogeographic affinity of a locality is to compare the total percentage of all species of the warm-water and cool-water assemblages. For instance, warm-water species in Trinidad (Table 1) constitute about $83 \%$ of the total, cool-water species less than $1 \%$. In contrast, at Site 605 the warm-water group totals about $17 \%$, whereas the cool-water group comprises up to $65 \%$ of the total assemblage. At Site 111 , the cool-water group totals nearly $86 \%$ and the warm-water group only $13 \%$. Table 1 shows that a distinct gradient in warm to cool localities, or vice versa, is evident in these two groups.

Q-mode cluster analysis of planktonic genera reveals a close affinity between Site 605, New Jersey, and Site 111 (Fig. 13A). R-mode factor analysis separates two groups which have paleobiogeographic significance, a 
A

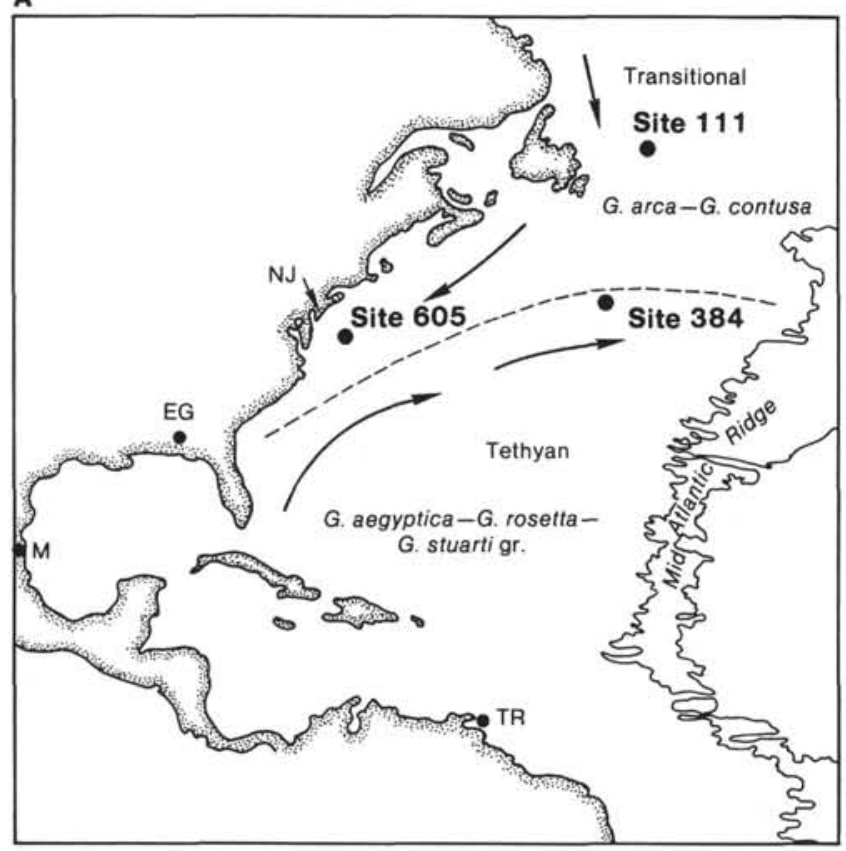

B

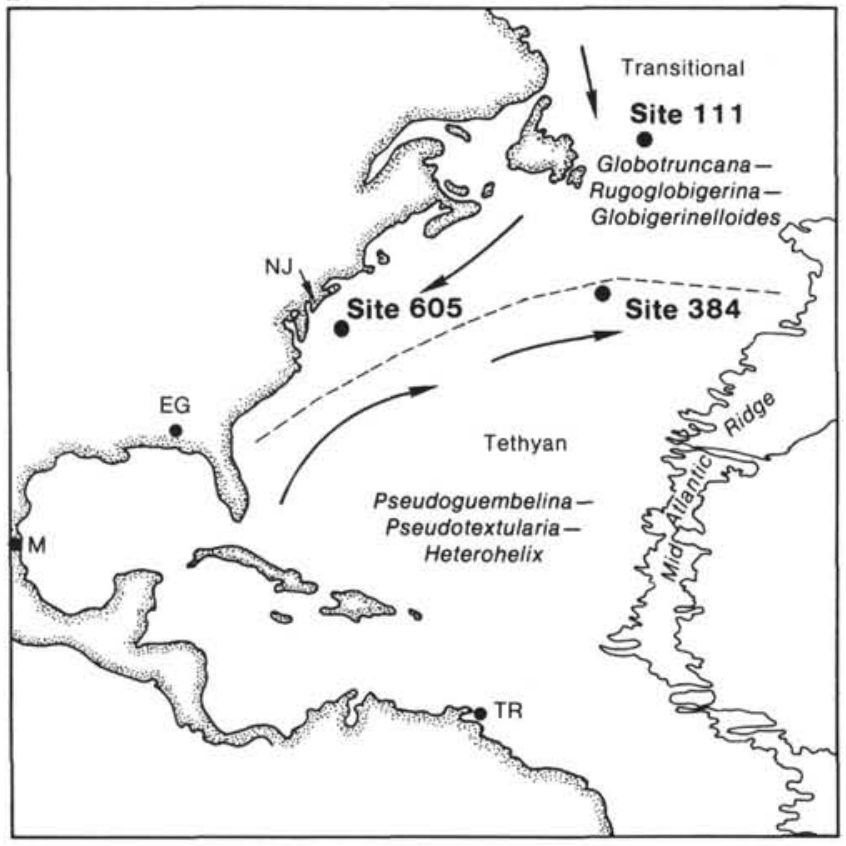

Figure 11. Paleobiogeographic maps of warm- and cool-water foraminiferal assemblages in the late Maestrichtian. Inferred circulation is shown. Boundary between transitional and Tethyan provinces after Nyong (1984). A. Globotruncana species. B. Planktonic genera.

warm-water group with Heterohelix, Pseudoguembelina, and Pseudotextularia as the dominant genera and coolwater group with Globotruncana, Rugoglobigerina, and Globigerinelloides as the dominant genera (Fig. 13B). Table 1 shows an inverse relationship of the total percentage of genera in each of the two groups similar to that of the warm- and cool-water species of Globotruncana.

The factor/cluster analyses of planktonic foraminifers establish that Site 605 and the New Jersey coastal plain were under a strong cool-water influence during late Maestrichtian time. The biogeographic analysis of Nyong (1984) indicates that cool-water influence began earlier, in the Campanian to early Maestrichtian. Nannofossil biogeographic analysis in offshore wells, eastern Canada, indicates the onset of a cooling trend in the early Maestrichtian in the northwest Atlantic, a trend which is related to the opening of the Labrador Sea (Doeven, 1983).

Strong cool-water influence southward from the northern Atlantic along the western Atlantic margin is also suggested by the occurrence of the late Maestrichtian high-latitude genus Nephrolithus (Fig. 14). In summary, paleobiogeographic reconstructions (Figs. 11, 14) indicate that a cool-water system began operating along the western Atlantic margin during late Campanian to early Maestrichtian time. The nature and strength of this system was sufficient to scour and erode this margin during late Campanian to early Eocene time.

The source of cool water was either in the region of the Labrador Sea or in that of the Norwegian-Greenland Sea, perhaps both. A marine connection through these seas to the Arctic Ocean is regarded as occurring during Paleocene and Eocene time (Gradstein and Srivastava, 1980; Talwani and Eldholm, 1977). Nevertheless, the paleobiogeographic data indicate that cool waters flowed far south along the western Atlantic margin. It is envisioned that epicontinental flow of Arctic waters to the Atlantic began during the early stages of the opening of the Labrador Sea and perhaps the NorwegianGreenland Sea as well. These waters flowed along the western Atlantic margin, perhaps diverted there by a strong clockwise gyre of Tethyan warm waters in the central North Atlantic. Why this system ceased along the western Atlantic margin in early Eocene time is uncertain. A high sea level during the early Eocene and a major turnover of abyssal benthic foraminiferal species at the Paleocene/Eocene boundary (Tjalsma and Lohmann, 1982) may perhaps be related to its demise.

\section{SUMMARY}

The East Coast Sequential Unconformity (ECSU) was formed by the merging of numerous unconformities which had developed during each depositional sequence. A chronostratigraphic chart (Fig. 15) of the ECSU illustrates the merging of hiatuses from the coastal plain and Site 605 into a single large hiatus. This chart contrasts with the chronostratigraphic chart of Vail et al. (1984), which shows idealized sequences in that there is no continuity within the sequences bounding the ECSU. The fact that sequences are divided into two parts by the ECSU argues for a mechanism for erosion in addition to subaerial exposure or canyon cutting. Also, the ECSU cannot be regarded as a downlap surface with a condensed section because at Site 605 , the basin was not starved of sediment. In fact, accumulation rates were higher there than in the coastal plain (Fig. 10). Condensed sections actually occur in the coastal plain in the lower glauconite beds of the Paleocene sequences, where rates of accumulation are less than $1 \mathrm{~cm} / 10^{3} \mathrm{yr}$. These condensed sequences conform with the concept of Vail 
A

0.000

Distances

20.000

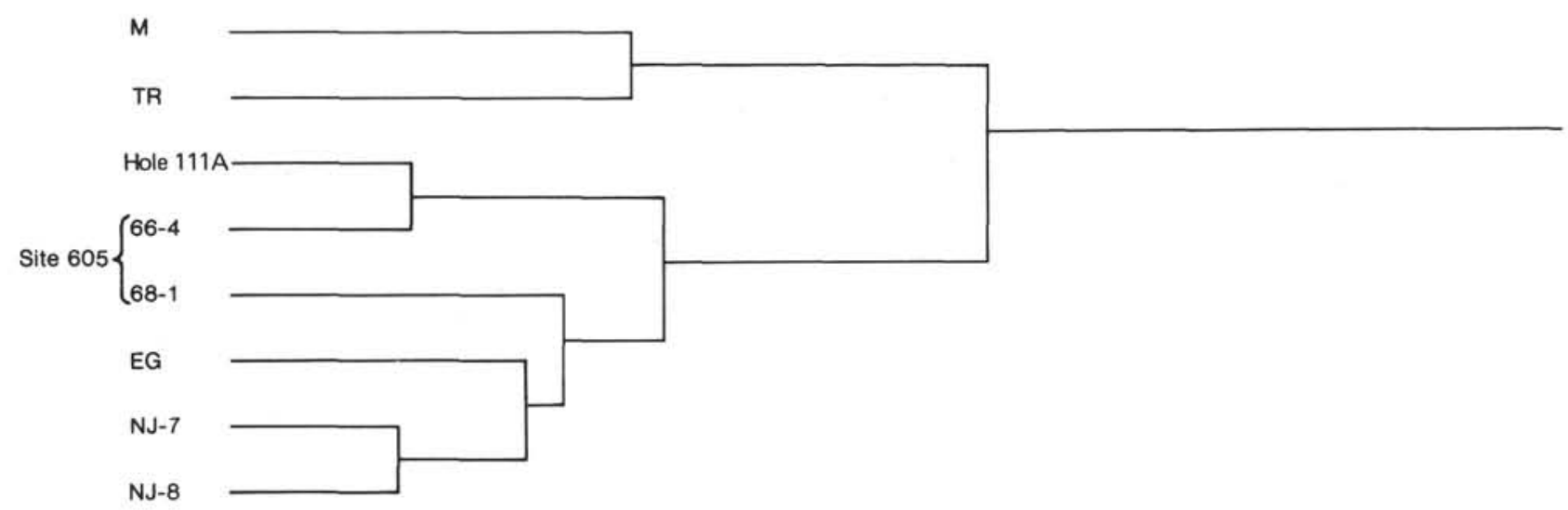

B

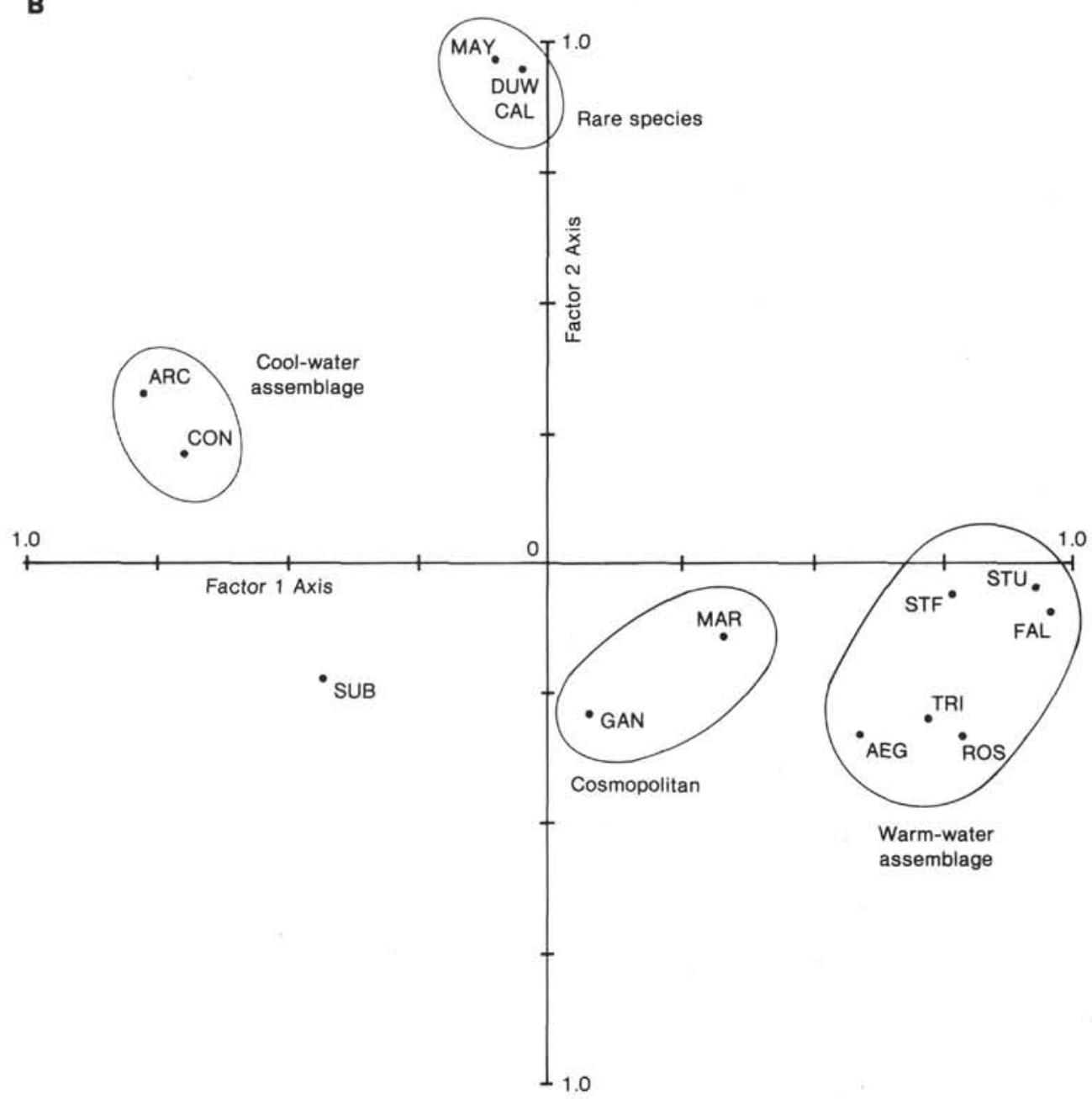

Figure 12. A. Q-mode cluster analyses of Globotruncana species using Pearson correlation coefficient. See Fig. 11 for locations. B. R-mode factor analysis showing grouping of Globotruncana species in the late Maestrichtian. Species abbreviations: $\mathrm{ARC}=a r c a, \mathrm{CON}=c o n t u-$ $s a, \mathrm{DUW}=d u w i, \mathrm{CAL}=$ calciformis, $\mathrm{MAY}=$ mayaroensis, $\mathrm{SUB}=$ subcircumnodifer, $\mathrm{MAR}=$ mariei, $\mathrm{GAN}=$ gansseri, $\mathrm{STU}=$ stuarti, $\mathrm{STF}=$ stuartiformis, $\mathrm{FAL}=$ falsostuarti, TRI $=$ tricarinata, $\mathrm{ROS}=$ rosetta, $\mathrm{AEG}=$ aegyptic $a$. 
Table 1. Distribution of late Maestrichtian warm-water and cool-water foraminiferal assemblages in the western North Atlantic region.

\begin{tabular}{|c|c|c|c|c|c|c|c|c|}
\hline \multirow{3}{*}{$\begin{array}{l}\text { Total \% of } \\
\text { assemblage }\end{array}$} & \multirow[b]{3}{*}{ Trinidad } & \multirow[b]{3}{*}{ Mexico } & \multirow{3}{*}{$\begin{array}{l}\text { Gulf } \\
\text { Coast } \\
\text { (EG) }\end{array}$} & \multirow{2}{*}{\multicolumn{2}{|c|}{ New Jersey }} & \multicolumn{3}{|c|}{ North Atlantic } \\
\hline & & & & & & \multirow{2}{*}{$\begin{array}{l}\text { Section } \\
605-66-4\end{array}$} & \multirow{2}{*}{$\begin{array}{l}\text { Section } \\
605-68-1\end{array}$} & \multirow{2}{*}{$\begin{array}{l}\text { Hole } \\
111 \mathrm{~A}\end{array}$} \\
\hline & & & & NJ 7 & NJ 8 & & & \\
\hline \multicolumn{9}{|c|}{ Globotruncana species } \\
\hline Warm-water & 82.9 & 79.9 & 56.4 & 33.3 & 28.5 & 17.3 & 22.0 & 13.1 \\
\hline Cool-water & 0.39 & 8.37 & 24.3 & 50.7 & 52.9 & 65.3 & 42.0 & 85.9 \\
\hline Total & 83.3 & 88.3 & 80.9 & 84.0 & 81.4 & 82.6 & 64.0 & 99.0 \\
\hline \multicolumn{9}{|l|}{ Planktonic genera } \\
\hline Warm-water & 73.9 & 71.4 & 78.1 & 44.0 & 37.0 & 50.0 & 36.4 & 22.1 \\
\hline Cool-water & 18.1 & 22.0 & 14.5 & 22.6 & 56.3 & 40.8 & 59.5 & 65.0 \\
\hline Total & 92.0 & 93.4 & 92.6 & 66.6 & 93.3 & 90.8 & 95.9 & 87.1 \\
\hline
\end{tabular}

Note: See Figs. 11, 12, and 13.

et al. (1984) in that they occur within a sequence and thus between unconformities. A condensed section may be present in the upper Paleocene sequence TP2.3 at Site 605 (see Saint-Marc, this volume).

Unconformities in the coastal plain and at Site 605 conform with type 1 and type 2 unconformities of Vail et al. (1984). A type 1 unconformity caused by a combination of subaerial and marine erosion separates the lower and middle Paleocene sequences TP1 and TP2.1; it is associated with reflector $\mathrm{A}^{*}($ ?) (Fig. 16). According to Vail et al. (1984) a type 1 unconformity develops when the rate of sea-level fall is greater than the rate of subsidence at the shelf edge. Another type 1 unconformity may be associated with sequence TP2.3. Type 2 unconformities, which are associated with sequences KM1, TP2.1, 2.2, and TE1.2, and 2.1 in the coastal plain (Fig. $15)$, are due to subaerial exposure of the landward portion of the shelf. They develop when the rate of sea-level fall is less than the rate of subsidence at the shelf edge. The hiatuses associated with type 1 and 2 unconformities in the coastal plain may merge with nondepositional hiatuses which are developed at the base of a sequence. The nondepositional hiatus results when sea level does not reach the coastal plain until some time after the rise commences. A slow rate of sea-level rise leads to this type of hiatus. Nondepositional hiatuses occur with sequences TP2.2, 2.3, and TE2.1 and possibly with TP1 (Fig. 15).

Drilling at Site 605 has helped clarify some of the problems in recognizing the sequences of Vail et al. (1977) in the Baltimore Canyon Trough. Stratigraphic modeling of the western Atlantic margin using data from the COST B-2 and B-3 wells of the Baltimore Canyon led Watts and Thorne (1984) and Thorne and Watts (1984) to question the usefulness of the sequence analysis technique of Vail et al. (1977, 1980, 1984). They emphasized that few unconformity-bounded sequences could be identified in continental shelves and that sequence boundaries are best defined on continental slopes or where there is active continental tilting. Using the record of the B-2 well, they derived a long-term sea-level curve that contained three cycles separated by sea-level falls in the $\mathrm{Pa}$ - leocene and in the Oligocene. It is not surprising that they were led to these conclusions, because they were analyzing a well where the major portion of the Maestrichtian and Paleocene sections are missing because of the ECSU. Integration and correlation of the coastal plain section and the section at Site 605 show, indeed, that sequences and their boundaries can be recognized and correlated across the Baltimore Canyon Trough. Nevertheless, the studies of Watts and Thorne (1984) and Thorne and Watts (1984) point out the difficulties that may be encountered in applying sequence stratigraphy in a basin where an active current system is affecting the preservation of the stratigraphic record. Data from wells, outcrops, and seismic sections are needed to thoroughly analyze the sequence stratigraphy of a basin.

Considerable attention has been directed at understanding the magnitude of sea-level change from Late Cretaceous times to the present. These studies have calculated sea-level changes based on subsidence history of passive margins (Hardenbol et al., 1981; Watts and Steckler, 1979; Watts and Thorne, 1984), mid-ocean-ridge volume changes (Pitman, 1978; Kominz, 1984), seismic stratigraphy (Vail et al., 1977), and continental hypsometry (Bond, 1979). Estimates of sea-level elevations at the maximum high stand in the late Cretaceous range from $100 \mathrm{~m}$ to over $300 \mathrm{~m}$ above present sea level. Watts and Steckler and Watts and Thorne have focused their analyses on subsidence calculations on the COST B-2 Well in the Baltimore Canyon Trough. Curves generated from these studies show maximum elevations in the Late Cretaceous near $100 \mathrm{~m}$ above present sea level.

The studies just mentioned are not constrained by paleoecologic criteria because few detailed analyses are available. Recently, Olsson and Nyong (1984) developed a paleoslope model of Campanian to lower Maestrichtian benthic foraminifers in the coastal plain of New Jersey and Delaware. They (Nyong and Olsson, 1984) extended this model to the Baltimore Canyon Trough and the western Atlantic basin using wells and Deep Sea Drilling sites. The paleoslope model shows the downdip geographic distribution of foraminifers in nearshore deposits in the coastal plain to abyssal environments in the At- 
A

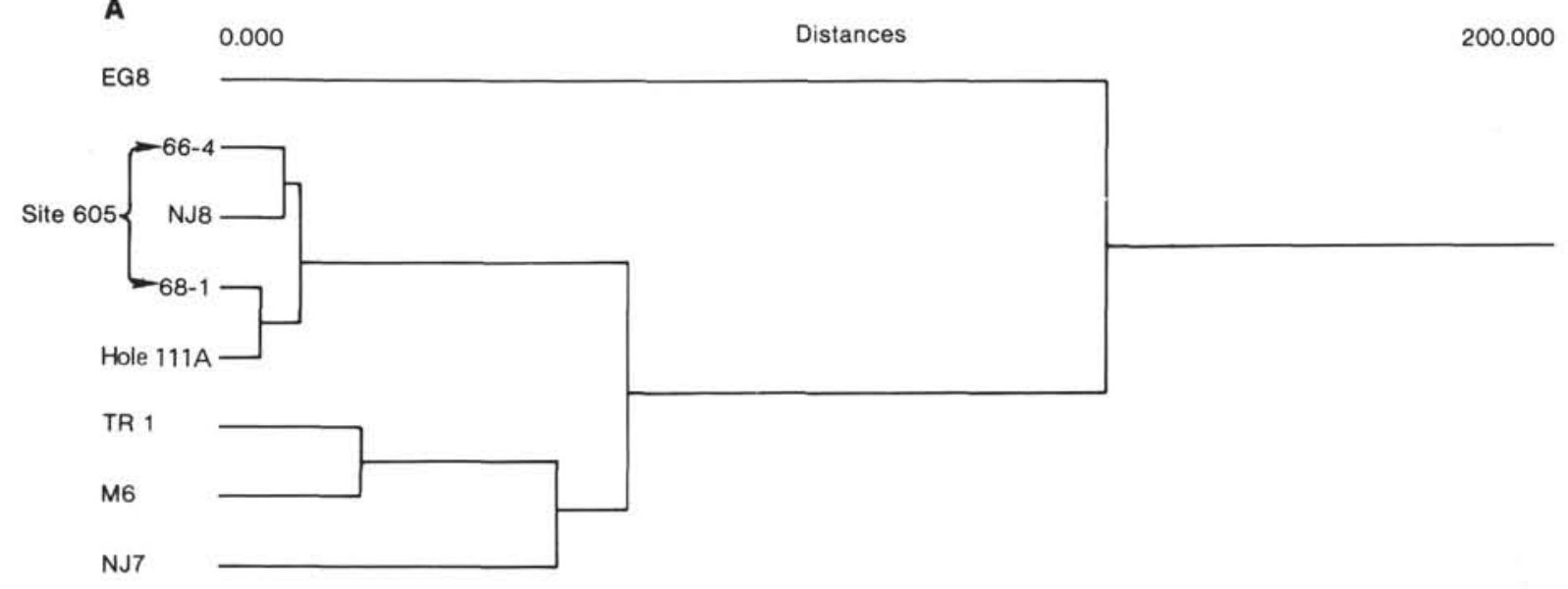

B

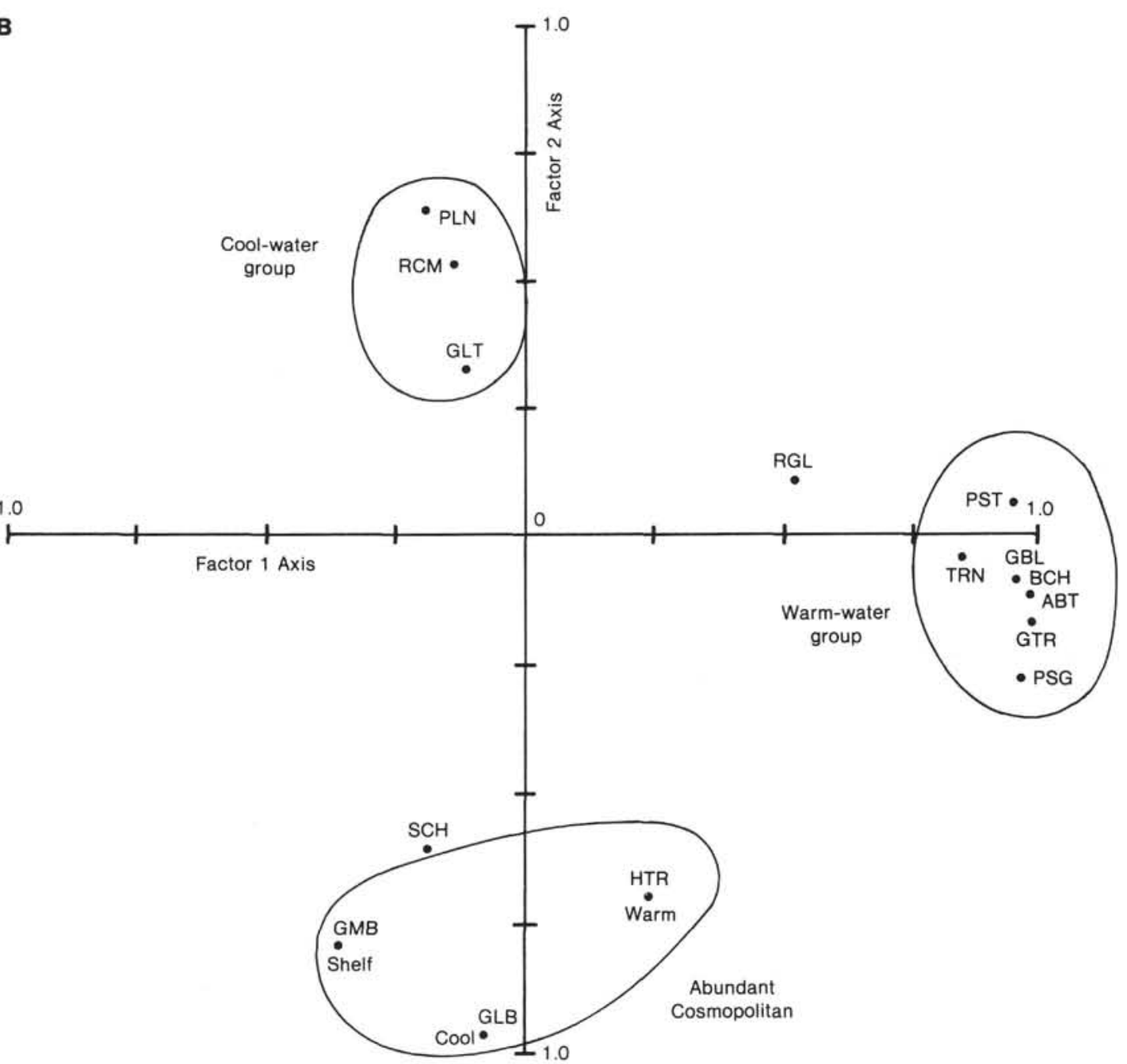

Figure 13. A. Q-mode cluster analysis of planktonic genera using Pearson correlation coefficient. See Fig. 11 for locations. B. Rmode factor analysis showing grouping of planktonic foraminiferal genera. Genera abbreviations: $\mathrm{ABT}=$ Abathomphalus, $\mathrm{BCH}$ $=$ Bucherina, $\mathrm{GBL}=$ Gublerina, $\mathrm{GLB}=$ Globigerinelloides, $\mathrm{GLT}=$ Globotruncana, $\mathrm{GMB}=$ Guembelitria, $\mathrm{GTR}=$ Globotruncanella, $\mathrm{HTR}=$ Heterohelix, $\mathrm{PLN}=$ Planoglobulina, $\mathrm{PSG}=$ Pseudoguembelina, $\mathrm{PST}=$ Pseudotextularia, $\mathrm{RCM}=R a-$ cemiguembelina, $\mathrm{RGL}=$ Rugoglobigerina, $\mathrm{TRN}=$ Trinitella . 


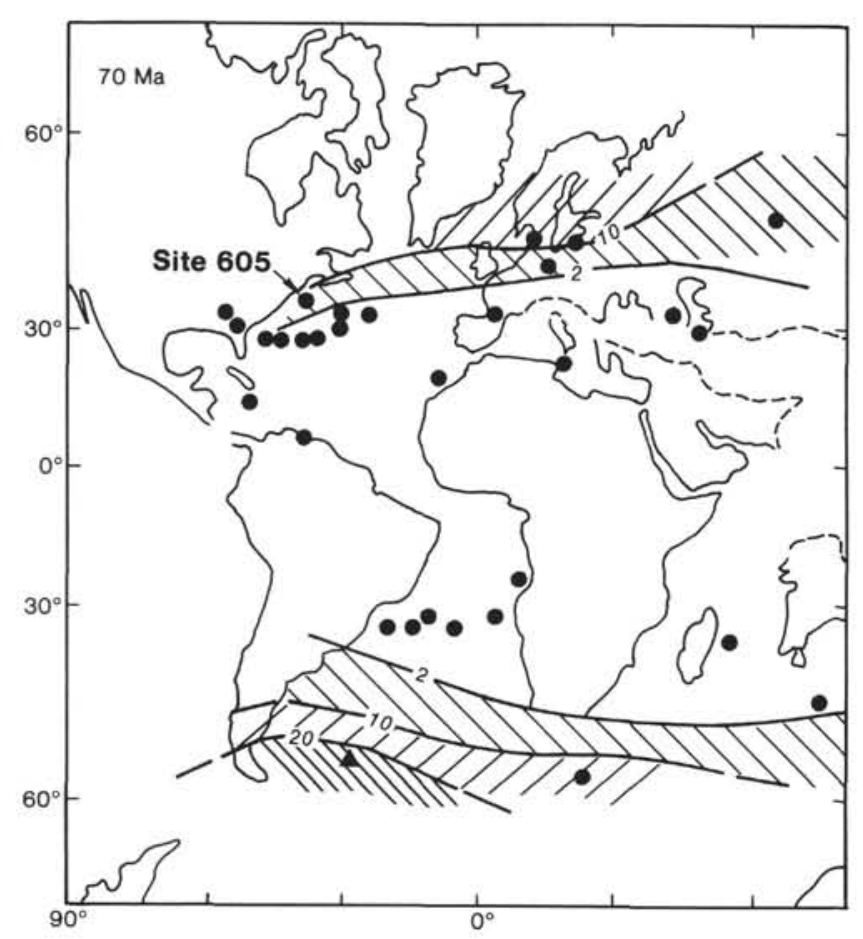

Figure 14. Paleobiogeographic map showing distribution of latest Maestrichtian calcareous nannofossil genus Nephrolithus. After Thierstein (1981) and modified to include data from Doeven (1983) and from Site 605 . lantic. Maximum sea-level elevation based on the paleoslope model in the late Campanian was approximately $80 \mathrm{~m}$ above present-day sea level. These estimates are taken on the outcrop belt in the coastal plain, which is about $20 \mathrm{~m}$ in elevation. Sea-level elevations may have been less because uplift in the coastal plain caused by flexture (Watts, 1981) is not considered in these estimates. Kominz's (1984) re-evaluation of the effect on sea level of changes in mid-ocean-ridge-crest volumes shows maximum possible sea-level elevations at $80 \mathrm{Ma}$ (Campanian) of $365 \mathrm{~m}$ and minimum elevations of $45 \mathrm{~m}$.

The paleodepth curve shown in Figure 4 for the coastal plain is from the paleoslope model and other studies (Olsson, 1980). It indicates sea-level variations of 40 to $100 \mathrm{~m}$ during the Campanian to the middle Eocene. The long-term trend shows an overall fall in sea level of about $40 \mathrm{~m}$. Superimposed on this trend are short-term changes which are similar to the high-order cycles of sea-level variations developed by Vail et al. (1977). Of note is the early Eocene high stand of about $120 \mathrm{~m}$. This high stand is also suggested by benthic foraminiferal changes in Site 612 (Miller and Katz, in press) and by nannofossil changes in Site 605 (Applegate and Wise, this volume). The paleodepth record in the coastal plain and the close correlation of sequences here and at Site 605 with the sequences of Vail and others support eustasy as a mechanism for short-term sea-level change, as proposed by Vail and others.

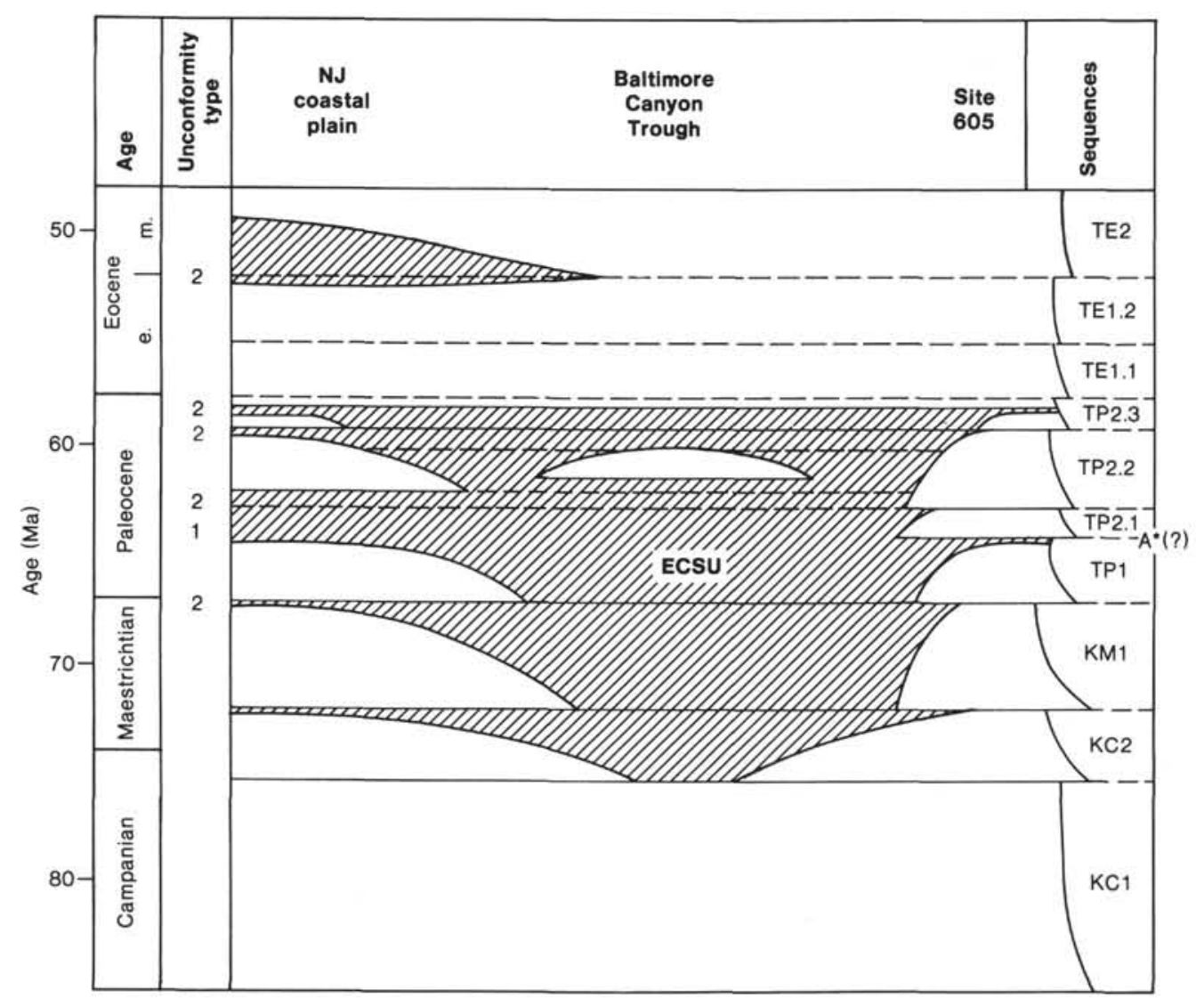

Figure 15. Model showing how the stratigraphic sequences of the New Jersey coastal plain and Site 605 relate to the East Coast Sequential Unconformity (ECSU) in the Baltimore Canyon Trough. Type 1 and type 2 unconformities (Vail et al., 1984) are noted for the coastal plain and Site 605. 


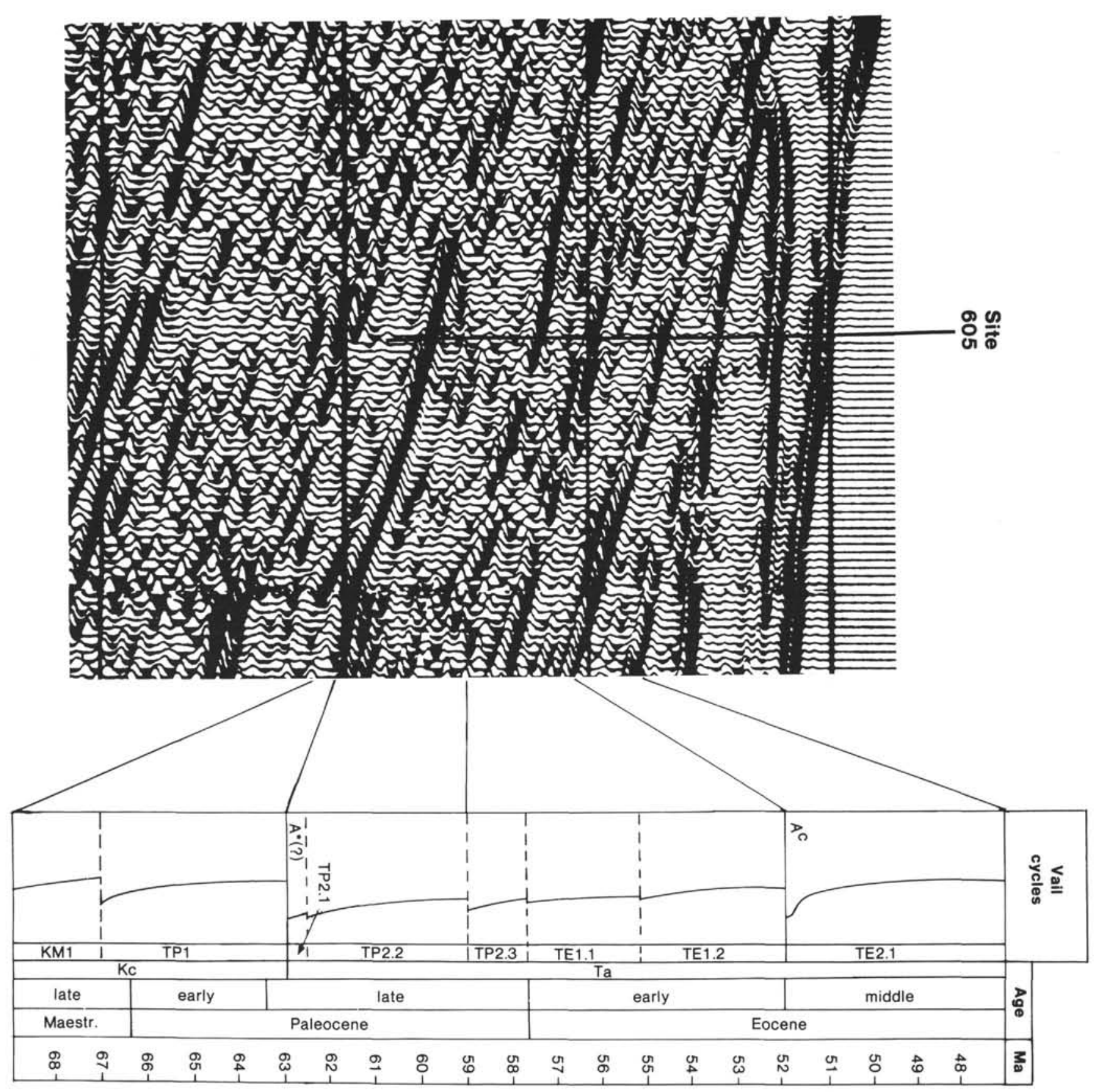

Figure 16. Segment of U.S.G.S. multichannel line 25 at Site 605 showing correlation of seismic horizons with Tertiary sequences of Vail et al. (1977).

\section{ACKNOWLEDGMENTS}

We thank our reviewers, G. S. Mountain and K. G. Miller, for their many constructive suggestions for improving the manuscript. Acknowledgment is made to the Donors of The Petroleum Research Fund, administered by the American Chemical Society, for partial support of this research.

\section{REFERENCES}

Berggren, W. A., Kent, D. V., and Flynn, J. J., 1985. Jurassic to Paleogene: Part 2. Paleogene geochronology and chronostratigraphy. In Snelling, N. J. (Ed.), The Chronology of the Geologic Record. Geol. Soc. London, Mem., 10:141-195.

Bond, G. C., 1979. Evidence for some uplifts of large magnitude in continental platforms. Tectonophysics, 61:285-305.
Charletta, A. C., 1980. Eocene benthic foraminiferal paleoecology and paleobathymetry of the New Jersey continental margin $[\mathrm{Ph} . \mathrm{D}$. dissert.]. Rutgers University, New Jersey.

Davids, R. N., 1966. A paleoecological and paleo-biogeographic study of Maestrichtian planktonic foraminifera. [Ph.D, dissert.]. Rutgers University, New Jersey.

Doeven, P. H., 1983. Cretaceous nannofossil stratigraphy and paleoecology of the Canadian Atlantic margin. Geol. Surv. Canada Bull., 356:1-69.

Gradstein, F. M., and Srivastava, S. P., 1980. Aspects of Cenozoic stratigraphy and paleoceanography of the Labrador Sea and Baffin Bay. Palaeogeogr., Palaeoclimatol., Palaeoecol., 30:261-295.

Hansen, H. J., 1974. Sedimentary facies of the Aquia Formation in the subsurface of the Maryland coastal plain. Maryland Geol. Surv., Rept. Investig. 21:1-47. 
Hardenbol, J., Vail, P. R., and Ferrer, J., 1981. Interpreting paleoenvironments, subsidence history and sea-level changes of passive margins from seismic and biostratigraphy. In Saint-Maur, G. P. de (Ed.), Geology of passive margins. Oceanol. Acta, 4(suppl.):33-44.

Hazel, J. E., Edwards, L. E., and Bybell, L. M., 1984. Significant unconformities and the hiatuses represented by them in the Paleogene of the Atlantic and Gulf coastal province. In Schlee, J. S. (Ed.), Interregional Unconformities and Hydrocarbon Accumulation. Am. Assoc. Pet. Geol. Mem., 36:59-66.

Hinte, J. E. van, Wise, S. W., Jr., Biart, B. N. M., Covington, J. M., Dunn, D. A., et al., 1985. Deep-sea drilling on the upper continental rise off New Jersey, DSDP Sites 604 and 605. Geology, 13: 397-400.

Koch, R. C., and Olsson, R. K., 1977. Dinoflagellate and planktonic foraminiferal biostratigraphy of the uppermost Cretaceous of New Jersey. J. Paleontol., 51:480-491.

Kominz, M. A., 1984. Oceanic ridge volumes and sea-level changean error analysis. In Schlee, J. S. (Ed.), Interregional Unconformities and Hydrocarbon Accumulation. Am. Assoc. Pet. Geol. Mem., 36:108-128.

Miller, K. G., and Katz, M. E., in press. Eocene benthic foraminiferal biofacies of the New Jersey transect. In Poag, C. W., Watts, A. B., et al., Init. Repts. DSDP, 95: Washington (U.S. Govt. Printing Office).

Mountain, G. S., and Tucholke, B. E., 1985. Mesozoic and Cenozoic geology of the United States Atlantic continental slope and rise. In Poag, C. W. (Ed.), Geologic Evolution of the United States Atlantic Margin: New York (Van Nostrand Reinhold), pp. 293-341.

Nyong, E. E., 1984. Campanian to lower Maastrichtian paleobiogeography of the western North Atlantic region. Eclogae Geol. Helv., 77:469-481.

Nyong, E. E., and Olsson, R. K., 1984. A paleoslope model of Campanian to lower Maestrichtian foraminifera in the North American Basin and adjacent continental margin. Mar. Micropaleontol., 8: 437-477.

Olsson, R. K., 1964. Late Cretaceous planktonic foraminifera from New Jersey and Delaware. Micropaleontology, 10:157-188.

1969. Early Tertiary planktonic foraminiferal zonation of New Jersey. In Brönnimann, P., and Renz, H. H. (Eds.), Proc. Ist Int. Conf. Planktonic Microfossils, Geneva, 1967: Leiden (E. J. Brill), pp. 493-504.

1980. The New Jersey coastal plain and its relationship with the Baltimore Canyon Trough. New York Geol. Assoc. 52nd Annual Meeting, Guidebook, pp. 116-129.

Olsson, R. K., and Nyong, E. E., 1984. A paleoslope model for Campanian-lower Maestrichtian Foraminifera of New Jersey and Delaware. J. Foraminiferal Res., 14:50-68.

Petters, S. W., 1977. Upper Cretaceous planktonic foraminifera from the subsurface of the Atlantic Coastal Plain of New Jersey. J. Foraminiferal Res., 7:165-187.

Petters, S. W., and Olsson, R. K., 1979. Planktonic foraminifera from the Ewekoro type section (Paleocene), Nigeria. Micropaleontology, 25:206-213.

Pinet, P. R., and Popenoe, P., 1985. A scenario of Mesozoic-Cenozoic ocean circulation over the Blake Plateau and its environs. Geol. Soc. Am. Bull., 96:618-626.

Pitman, W. C., III, 1978. Relationship between eustacy and stratigraphic sequences of passive margins. Geol. Soc. Am. Bull., 89: 1389-1403.

Poag, C. W., 1980. Foraminiferal stratigraphy, paleoenvironments, and depositional cycles in the outer Baltimore Canyon trough. Geol. Surv. Circular, 833:44-66.

Poag, C. W., and Schlee, J. S., 1984. Depositional sequences and stratigraphic gaps on submerged United States Atlantic margin. In Sch- lee, J. S. (Ed.), Interregional Unconformities and Hydrocarbon Accumulations. Am. Assoc. Pet. Geol. Mem., 36:165-182.

Poag, C. W., Watts, A. B., et al., in press. Init. Repts. DSDP, 95: Washington (U.S. Govt. Printing Office).

Richards, H. G., and Gallagher, W., 1974. The problem of the Cretaceous-Tertiary boundary in New Jersey. Not. Nat., 449:1-6.

Robb, J. M., Hampton, J. C., Jr., Kirby, J. R., and Twichell, D. C., 1981. Geology and Potential Hazards of the Continental Slope Between Lindenkohl and South Toms Canyon Offshore Mid-Atlantic United States. U.S. Geol. Surv. Open-File Rept., 81-600.

Smit, J., 1982. Extinction and evolution of planktonic foraminifera after a major impact at the Cretaceous/Tertiary boundary. In Silver, L. T., and Schultz, P. H. (Eds.), Geologic Implications of Impacts of Large Asteroids and Comets on the Earth. Geol. Soc. Am. Spec. Pap., 190:329-352.

Talwani, M., and Eldholm, O., 1977. Evolution of the NorwegianGreenland Sea. Geol. Soc. Am. Bull., 88:969-999.

Thierstein, H. R., 1981. Late Cretaceous nannoplankton and the change at the Cretaceous-Tertiary boundary. In Warme, J. E., Douglas, R. G., and Winterer, E. L. (Eds.), The Deep Sea Drilling Project: A Decade of Progress. Soc. Econ. Paleontol. Mineral., Spec. Publ., 32:355-394.

Thorne, J., and Watts, A. B., 1984. Seismic reflectors and unconformities at passive continental margins. Nature, 311:365-368.

Tjalsma, R. C., and Lohmann, G. P., 1982. Paleocene-Eocene Bathyal and Abyssal Benthic Foraminifera from the Atlantic Ocean. Micropaleontology, Spec. Publ. 4.90.

Tucholke, B. E., 1979. Relationships between acoustic stratigraphy and lithostratigraphy in the western North Atlantic basin. In Tucholke, B. E., Vogt, P. R., et al., Init. Repts. DSDP, 43: Washington (U.S. Govt, Printing Office), 827-846.

Tulchoke, B. E., and Mountain, G. S., 1979. Seismic stratigraphy, lithostratigraphy, and paleosedimentation patterns in the North Atlantic basin. In Talwani, M., Hay, W., and Ryan, W. B. F. (Eds.), Deep Drilling Results in the Atlantic Ocean: Continental Margins and Paleoenvironment. Am. Geophys. Union, Maurice Ewing Ser., 3:58-86.

Vail, P. R., Hardenbol, J., and Todd, R. G., 1984. Jurassic unconformities, chronostratigraphy, and sea-level changes from seismic stratigraphy and biostratigraphy. In Schlee, J. S. (Ed.), Interregional Unconformities and Hydrocarbon Accumulations. Am. Assoc. Pet. Geol. Mem., 36:129-144.

Vail, P. R., Mitchum, R. M., Jr., Shipley, T. H., and Buffler, R. T., 1980. Unconformities of the North Atlantic. R. Soc. London Phil. Trans., 294:137-155.

Vail, P. R., Mitchum, R. M., Jr., and Thompson, S., III, 1977. Seismic stratigraphy and global changes of sea level, Part 3: relative changes of sea level from coastal onlap. In Payton, C. E. (Ed.), Seismic Stratigraphy: Application to Hydrocarbon Exploration. Am. Assoc. Pet. Geol. Mem., 26:63-81.

Watts, A. B., 1981. Tectonic subsidence, flexure and global changes of sea level. Nature, 297:469-474.

Watts, A. B., and Steckler, M. S., 1979. Subsidence and eustacy at the continental margin of eastern North America. In Talwani, M., Hay, W., and Ryan, W. B. F. (Eds.), Deep Drilling Results in the Atlantic Ocean: Continental Margin and Paleoenvironment. Am. Geophys. Un., Maurice Ewing Ser., 3:218-234.

Watts, A. B., and Thorne, J., 1984. Tectonics, global changes in sea level and their relationship to stratigraphical sequences at the U.S. Atlantic continental margin. Mar. Pet. Geol., 1:319-339.

Date of Initial Receipt: 5 August 1985

Date of Acceptance: 7 May 1986 